\title{
LA EXPULSIÓN DE LAS REPRESENTACIONES DEL TEMPLO (LOS AUTOS SACRAMENTALES Y LA CRISIS DEL CORPUS DE TOLEDO, 1613-1645)
}

\section{FERNANDO MARTÍNEZ GIL}

Universidad de Castilla-La Mancha

RESUMEN: Calderón de la Barca estrenó algunos autos sacramentales en Toledo, pero nunca fueron representados en el interior de la catedral, como había sucedido durante siglos. Por el contrario, su escenario fue un tablado en la plaza pública, frente al Ayuntamiento de la ciudad. Años antes, entre 1614 y 1617, y después de un intenso debate, los canónigos de la catedral babían decidido romper con la tradición y expulsar a los autos del interior del templo. Este hecho no es una simple anécdota, sino que refleja un interesante cambio en las mentalidades y en las formas de entender la religiosidad y la fiesta. Los autos fueron un elemento esencial de la fiesta del Corpus; en el siglo XVII, sin embargo, ya no se consideraban apropiados a los espacios sagrados; finalmente, en el siglo XVIII, fueron definitivamente probibidos.

Palabras clave: Autos sacramentales. Corpus Christi. Teatro. Toledo. Contrarreforma.

ABSTRACT: Some of Calderón de la Barca's sacramental plays were premiered in Toledo, but they were never performed inside the Cathedral, as in the previous centuries. On the contrary, they were shown on a stage in the city square, opposite the town hall building. A few years earlier, between 1614 and 1617, and after an intense debate, the Cathedral canons had decided to break the tradition and expel the plays from inside the temple. This fact is not just an anecdote; it reflects an interesting change in mentalities and in the way in which religiousness and feasts were now understood. The plays were an essential element in the Feast of Corpus Christi; nevertheless, in the 17th century, religious spaces were no longer considered appropiate. Those plays were definitely forbidden in the 18th century.

KEY WORDs: Religious Plays. Corpus Christi. Theatre. Toledo. Counter-Reformation. Festivals Religiousness 


\section{PlanTEAMIENTO: SALIDA DEL CARRO DE REPRESENTANTES}

La ciudad de Toledo, volcada de antiguo a la celebración de la fiesta del Corpus, es un buen observatorio para seguir la evolución del auto sacramental, un género teatral que se enmarca con toda exactitud dentro del Antiguo Régimen. Enraizado en los primitivos autos medievales, define su personalidad en el siglo XVI, llega a su máximo desarrollo con Calderón y termina siendo prohibido por Carlos III en 1765. Calderón de la Barca, capellán de Reyes Nuevos de la catedral primada, escribió varios autos para ser estrenados en Toledo, como Psiquis y Cupido o La humildad coronada, pero para entonces las representaciones ya no se hacían en el interior de la catedral, sino sobre tablados dispuestos en las plazas del Ayuntamiento y de Zocodover. Durante más de un siglo, al menos, los autos habían sido patrocinados por el cabildo de la catedral, ante el que se escenificaban, entre los dos coros, previamente a que saliera la procesión del Corpus. El más rico templo de España no sólo podía permitirse mantener a la mejor capilla musical, comparable a la Real, sino que tenía a gala el esplendor con que celebraba sus actividades litúrgicas y sus festividades religiosas. Y entre ellas cobró inusitada pujanza la fiesta del Santísimo Sacramento, sobre todo desde que se hicieron patentes las amenazas de las herejías protestantes ${ }^{1}$. Junto a las danzas, toros y otros elementos profanos de la fiesta, eran sus acontecimientos centrales la procesión y la representación de los autos en el interior de la catedral, y para garantizar el brillo de una y otra el cabildo no escatimó en medios ${ }^{2}$. Todos los años se contrataban para esta ocasión las mejores compañías de farsantes, a cuyo reclamo respondía una numerosa concurrencia que daba realce y prestigio a la fiesta. De estas representaciones dijo Villalba en El peregrino curioso que «son las mejores que se hacen en ninguna parte porque se precian los que rigen esta Catedral de tener el mejor pantomimo representante que hay, y como es la flor de la lengua en Toledo y de los farsantes, échase de ver mucho la ventaja» ${ }^{3}$. Ciertamente el prestigio ya venía de antiguo. El conocido auto de los Reyes Magos procede del archivo catedralicio y la documentación capitular demuestra la existencia de un floreciente teatro religioso a lo largo del siglo XV, muestra del cual es el Auto de la Pasión no ha mucho descubierto ${ }^{4}$. Pioneros del género, como Gómez Manrique,

1 Martínez Gil, Fernando, y RodríGuez GonzÁlez, Alfredo: «Oposición y conflicto en una fiesta del Antiguo Régimen: el Corpus Christi», en la obra colectiva La Fiesta del Corpus Christi, Cuenca, Universidad de Castilla-La Mancha, 2002, pp. 43-65.

2 RodrígueZ De GRACIA, Hilario: El Corpus de Toledo. Fiesta religiosa y profana en los siglos XVI y XVII, Toledo, Caja Castilla-La Mancha, 2001. Y sobre los orígenes de la fiesta en la ciudad, GonZÁlveZ RuIZ, Ramón: «El Corpus de Toledo en los siglos XIV y XV», Memoria Ecclesiase (Oviedo), 20 (2001), pp. 211-240.

3 Citado por DíEZ Del Corral GarniCa, Rosario: Arquitectura y mecenazgo. La imagen de Toledo en el Renacimiento, Madrid, Alianza, 1987, p. 303.

4 El avance de este hallazgo en Torroja Menéndez, Carmen, y Rivas Palá, María: «Teatro religioso toledano en 1500», en V Simposio «Toledo Renacentista» (Centro Universitario de Toledo, 24- 
estuvieron muy ligados a la ciudad del Tajo, que luego sería cuna de autores tan renombrados como José de Valdivielso, Luis Quiñones de Benavente o Francisco de Rojas Zorrilla, así como albergue ocasional de Lope, Tirso, Moreto o el mismo Calderón ${ }^{5}$. Lo mismo cabe decir de las compañías teatrales y de sus directores. No sin fundamento aseguraba Agustín de Rojas Villandrado que «los famosos autores que han ilustrado nuestro oficio y puesto en el punto que agora vemos han sido todos naturales de Toledo». Y añadía: «Pues representantes los mejores que ha habido en nuestro oficio también han sido de Toledo» ${ }^{6}$.

El auge de los autos sacramentales fue producto de una determinada coyuntura histórica que no tardaría en cambiar. Los ilustrados del siglo XVIII ya no se mostraron predispuestos a entender las alegorías y rechazaron todo lo que de inconveniente y profano veían en esas antiguallas ridículas. En consecuencia, los autos y comedias de santos fueron prohibidos «por ser los teatros lugares muy impropios y los comediantes instrumentos muy indignos y desproporcionados para representar los Sagrados Misterios» ${ }^{7}$. No obstante, las muestras de incomprensión de los autos son muy anteriores, pudiéndose encontrar en plena eclosión del Barroco y del espíritu contrarreformista. Si, como quiere la teoría tradicio$\mathrm{nal}^{8}$, los autos sacramentales nacieron para dar respuesta a las herejías que negaban la presencia real de Cristo en la eucaristía, es difícil entender que, medio siglo después de que Trento cerrase sus puertas, una institución tan católica e influyente como el cabildo toledano expulsase a las representaciones de su templo y, mucho más llamativo, se desentendiese de ellas por completo, renunciando así a uno de sus instrumentos pedagógicos supuestamente más eficaces.

Tal circunstancia, que no debe ser descuidada como síntoma de un más amplio cambio de mentalidades, ocurrió exactamente en 1615, el año en que se publicó la segunda parte del Quijote. La obra de Cervantes deja constancia de la aceptación de los autos del Corpus no ya en ambientes selectos sino en los

26 abril 1975), Toledo, Publicaciones del Centro Universitario de Toledo, 1980, tomo III, pp. 111124; pero véase sobre todo Teatro en Toledo en el siglo XV. «Auto de la Pasión» de Alonso del Campo, Madrid, Anejos del Boletín de la Real Academia Española (Anejo 35), 1977.

5 Milego, Julio: El teatro en Toledo durante los siglos XVI y XVII, Valencia, Establecimiento tipográfico de Manuel Pau, 1909.

6 Rojas Villandrado, Agustín de: El viaje entretenido, ed. de Jean Pierre Ressot, Madrid, Castalia, 1995, libro II, p. 284. Entre los directores de compañías cita a Alonso de Cisneros, Jerónimo Velázquez, Tomás de la Fuente, Angulo el Malo, Juan de Alcocer y Gabriel de la Torre; y entre los representantes a «Ramírez y Solano, Nobles, Navarrico, Quirós, Miguel Ruiz, Marcos Ramírez, Loyola y otros muchos que no me acuerdo». Toledanos eran los contertulios del propio Rojas, a quienes convierte en los personajes protagonistas de su obra miscelánea: Nicolás de los Ríos, Miguel Ramírez y Agustín Solano.

7 Arellano, Ignacio, y Duarte, J. Enrique: El auto sacramental, Madrid, Ediciones del Laberinto, 2003, p. 161.

8 La discusión sobre los orígenes del auto sacramental en WARDROPPER, Bruce W.: Introducción al teatro religioso del Siglo de Oro, Salamanca, Anaya, 1967, sobre todo en el capítulo XI: «Los autos sacramentales como fenómeno histórico», p. 117 y ss. 
populares de las fiestas rurales, en las que no solían faltar. Los protocolos notariales documentan suficiente número de casos reales como para otorgar verosimilitud al del pastor estudiante Grisóstomo, quien «hacía los villancicos para la noche del Nacimiento del Señor, y los autos para el día de Dios, que los representaban los mozos de nuestro pueblo»"; o al encuentro de don Quijote con los farsantes de la compañía de Angulo el Malo, toledano por cierto, cuando se desplazaban de un pueblo a otro para representar el auto de Las cortes de la muerte en el día de la octava del Corpus ${ }^{10}$. Sorprende, pues, que fuese precisamente el clero capitular quien la emprendiese contra una costumbre tan arraigada y en apariencia tan afín a sus intereses doctrinales. Las actas del cabildo demuestran que no fue una decisión fácil ni unánimemente compartida, pues sólo se llegó a ella después de un prolongado debate que dividió a los canónigos en dos grupos bien diferenciados. Aun antes de que llegasen a su culminación con Calderón, los autos vieron así peligrar su continuidad en una ciudad tan emblemática como Toledo, pero la prohibición, unida a las dificultades económicas, sumió también en una profunda crisis a la fiesta del Corpus, que no conseguiría levantar cabeza en veinte años. Las páginas que siguen tratarán de analizar los cambios de sensibilidad que llevaron a esta ruptura con la tradición y de valorar sus consecuencias históricas.

\section{PRIMER AUTO: EL SIGLO XVI}

En un principio, al parecer, eran los propios clérigos los que representaban dentro de su iglesia los autos referidos a la Navidad, Semana Santa y Corpus Christi. El concilio toledano de 1565, sin embargo, mostró su desagrado por las danzas y espectáculos que perturbaban los oficios divinos y prohibió a los clérigos que se pusiesen máscaras y participasen en representaciones ${ }^{11}$. Desde entonces el cabildo habría recurrido a compañías profesionales que eran contratadas por los mayordomos para que hiciesen los autos en el día del Corpus y su octava, aunque los libros de obra y fábrica dejan constancia de que Lope de Rueda ya se había encargado de los autos al menos en los años 1561, 1562 y

9 Cervantes SaAvedra, Miguel de, El ingenioso hidalgo don Quijote de la Mancha, I Parte, capítulo XII, en Obras completas, Madrid, Aguilar, 2003, p. 46. Un valioso corpus documental, obtenido de los protocolos notariales de Toledo, en SAn Roman, Francisco de Borja: Lope de Vega, los cómicos toledanos y el poeta sastre, Madrid, Cuerpo Facultativo de Archiveros, Bibliotecarios y Arqueólogos, 1935.

10 El ingenioso hidalgo..., ed. cit., II Parte, capítulo XI, p. 335 y ss. Sobre el Corpus en los medios rurales y los desplazamientos de las compañías teatrales, véase el interesante artículo de SALOMON, Noël: «Sur les représentations théâtrales dans les «pueblos» des provinces de Madrid et Tolède (1589-1640)», Bulletin Hispanique, 62 (1960), pp. 398-427.

11 Fernández Collado, Ángel: Concilios toledanos postridentinos, Toledo, Diputación Provincial, 1996, p. 136. 
$1563^{12}$. Por medio de esta documentación pueden seguirse año a año los conciertos de los mayordomos con los distintos autores de comedias, así como su identidad y las cantidades que les eran libradas por su trabajo. Los canónigos eran los primeros en asistir a las representaciones y no pusieron objeciones en que continuasen desarrollándose en sagrado. Entre las pocas incidencias a reseñar en estos años cabe destacar la queja del tesorero don Pedro González de Mendoza, en mayo de 1577, de que los autos retrasaban en exceso la salida de la procesión, dando lugar a que el calor la desluciese. Mendoza pidió, en consecuencia, que la representación de los autos fuese trasladada a la tarde. Aunque la decisión se pospuso hasta la llegada de un nuevo arzobispo, parece que así se hizo desde 1579, hasta que en 1588 se dispuso que se representasen dos autos por la mañana, acabada prima, y tres por la tarde ${ }^{13}$. Por lo demás, los canónigos se mostraron en todo momento orgullosos de sus representaciones, como cuando, en 1581, el corregidor prohibió que se hiciesen los autos fuera de la iglesia, por motivos que se nos escapan. El cabildo se mostró unánime en "poner mucha diligencia en que no se disminuya en nada esta fiesta tan solemne y de tanta devoción como se tiene y deve tener al Santísimo Sacramento y haver novedad causa muchó escándalo en la ciudad» ${ }^{14}$. Cuando un nuevo concilio provincial volvió a prohibir que durante la celebración de los oficios divinos se representasen en el templo comedias, tragedias, ni aún de temas sagrados, farsas ni danzas ${ }^{15}$, los autos del Corpus no fueron afectados y continuaron representándose, como solían, en el crucero de la catedral.

La documentación capitular nos ofrece abundante información sobre la forma en que se festejaba el día del Corpus, del que, junto a la procesión, los autos constituían uno de sus platos fuertes. En 1579, por ejemplo, la compañía contratada debía hacer cuatro autos y una farsa sacramental, «y lo han de representar entre los dos coros y delante de la puerta mayor y de las casas del señor arcediano y en la plaça Mayor y en la plaza de los Cambios y en el Solarejo y en la plaça de Zocodover», para lo cual debían proporcionárseles los carros necesarios ${ }^{16}$. Como indica Juan de Chaves Arcayos en su memorial de finales de

12 ARCHIVO CAPITULAR DE LA CATEDRAL DE TOLEDO (en adelante ACT), Obra y Fábrica (en adelante $O F$ ), años 1561-1563. Lope de Rueda se encargó, al parecer, de la totalidad de los autos del Corpus en 1561 y 1562. Al año siguiente representó tres, recayendo los restantes en Pedro de Barnuevo y Melchor de Herrera.

13 ACT, Actas Capitulares (en adelante AC), 23-5-1577, 9-5-1580, 23-5-1581, 13-6-1582 y 85-1588. También por la tarde se hacía una procesión, y la representación de los cinco autos retrasaba su salida hasta que casi caía la noche. En 1591 volvieron a hacerse todos los autos por la tarde, pero se debió a la participación del rey en la procesión de la mañana.

14 AC, 23-5-1581.

15 Fernández Collado, Ángel: El concilio provincial de Toledo de 1582, Roma, Iglesia Nacional Española, 1995, p. 112.

16 Torroja Menéndez, Carmen: Catálogo del Archivo de Obra y Fábrica de la Catedral de Toledo, Toledo, Diputación Provincial, 1977, p. 415, doc. 1.312, jueves 2 de abril de 1579. Esta serie de lugares se corresponde con el itinerario de la procesión del Corpus. 
siglo, los canónigos y el clero catedralicio asistían antes de la procesión a la representación de un auto entre los dos coros, y en acabándolo,

«van caminando los carros en que los hacen por la nave mayor de Sant Cristóbal y salen fuera de la puerta Llana, adonde son obligados a tornar haçer el dicho Auto al Ayuntamiento desta çibdad, que están en un tablado y entapiçado que el dicho Ayuntamiento tiene fecho a su costa enfrente de la dicha puerta Llana, y los que están obligados a haçer estos Autos los haçen asimismo después de los haver hecho al Cabildo e Ayuntamiento enfrente de las casas del Arçediano de Toledo, y después, en la calle de la Tripería»17.

La abundante información extraída de los protocolos por San Román confirma estos detalles. En la última década del siglo XVI se representaban en el día del Corpus cinco autos con sus entremeses (dos por la mañana y tres por la tarde), y en la octava dos autos, dos entremeses y alguna comedia, a ser posible los que hubieran sido representados en Madrid el día del Santo Sacramento; unos años después, ya comenzado el siglo siguiente, los autos y entremeses se redujeron a cuatro (dos en la mañana y dos en la tarde), sin que en la octava se registrasen cambios $^{18}$. Algunas escrituras muestran la diferencia que se establecía entre los viejos autos de raíz medieval y los autos sacramentales. En los contratos de 1593 y 1595 se especifica que uno de los cinco autos deberá ser una «farsa sacramental»; en 1613 y 1614 se estipula que dos serán «autos sacramentales» y los otros dos «de historias vidas o martirios de santos». En 1592 y 1593 encontramos la mención de que el cabildo deberá poner a disposición de los comediantes los carros necesarios, uno por cada auto (por tanto, cinco carros el día del Corpus, y dos en la octava), pero en los años siguientes desaparece dicha información ${ }^{19}$. No obstante, los escenarios móviles debieron mantenerse, pues en todos estos años no variaron los lugares en que se hicieron las representaciones: primero dentro de la catedral, entre los dos coros, ante el cabildo y el clero del templo primado; luego ante el «tablado de la ciudad», situado frente a la Puerta del Perdón y las casas del Deán; y en fin, siguiendo a la procesión: las casas del Arcediano, la Tripería, Cerería, plaza Mayor, Cuatro Calles y Zocodover.

Los incidentes de que se hacen eco las actas capitulares no dejan de ser meras anécdotas, como la ocurrida en 1598, cuando el cabildo hubo de intervenir

17 ACT, Ms. 42-29, f. 536.

18 ACT, AC. 13-6-1603.

19 Dice Villalva en El peregrino curioso: «Van en unos carretones a representar, como mejor pueden, por ser Toledo, en muchas partes áspero». DíEZ DEL CORRAL GARNICA, Rosario: ob. cit., p. 303. Estos carros eran arrastrados por peones que, a fines del siglo XV, oscilaban entre 92 y 130. TORroja y María RIVAS, Carmen: ob. cit., p. 44. De la dureza y peligrosidad de este trabajo da idea esta información extraída de la $O F, 27-11$-1564: por mandato del gobernador Tello Girón le es concedida a Melchor de Aguilar una limosna de $7.500 \mathrm{mrs}$, «attento a que un carro de la fiesta del santísimo sacramento le cortó un brazo en años passados». 
prohibiendo uno de los autos, atento a que era escandaloso, y conminó a los mayordomos para que lo sustituyesen por otro decente ${ }^{20}$. Pero ello no llevó a los canónigos a cuestionar la oportunidad de los autos, sino a controlarlos más estrechamente. Todavía en 1603 se registra el acuerdo de que las representaciones debían hacerse dentro de la iglesia y en el lugar acostumbrado; los entremeses se harían con toda decencia, sin huella de profanidad, sin que hubiera cantores, tonadas y bailes deshonestos; y en ninguno de los autos debía introducirse «persona de la Santísima Trinidad ni de Nuestra Señora ni del Sumo Pontífice» ${ }^{21}$. En junio de 1604 , incluso, el propio arzobispo asistió a las representaciones desde el tablado reservado al cabildo ${ }^{22}$.

$Y$, sin embargo, ya existía por entonces una corriente rigorista que censuraba toda clase de representaciones en el interior de las iglesias y que comenzó a manifestarse en las disposiciones de concilios y sínodos. En la propia Toledo residía uno de los más influyentes fustigadores del teatro, el jesuita Juan de Mariana, autor de un Tratado contra los juegos públicos ${ }^{23}$, en el que no perdió oportunidad de censurar aquellos entremeses en que, so capa de devoción, se recitaban adulterios, amores torpes y otras deshonestidades.

«Yo antes creería que todos estos juegos se debrían desterrar de los templos sanctíssimos como estiércol y burla de la religión, principalmente cuando se hacen por públicos faranduleros, porque siendo su vida torpe, parece que con su misma afrenta afean antes la religión» ${ }^{24}$.

Mariana da por zanjado el asunto, dado que por ley eclesiástica ya estaba vedado hacer juegos teatrales en los templos. Sus argumentos, la mezcla de religión y profanidad y la deshonestidad de los que representan personajes santos, serían enarbolados muy pronto por aquellos clérigos para quienes los autos del Corpus no debían ser una excepción.

20 AC, 9-5-1580. El día 23 se libraron a Gaspar de Porras, autor de comedias, 200 reales por el auto que representó en vez del que estaba estudiado.

21 AC, 26-5-1603.

22 AC., 16-6-1604.

23 En Obras del Padre Juan de Mariana, Madrid, Atlas, 1950, tomo XXXI de la Biblioteca de Autores Españoles, pp. 413-462.

24 Ibidem, p. 423. «¿Cómo puede ser conviniente que hombres torpes representen las obras y vidas de los sanctos, y se vistan las personas de san Francisco, sancto Domingo, la Magdalena, los apóstoles y del mismo Cristo? ¿No es esto mezclar el cielo con la tierra o, por mejor decir, con el cieno, las cosas sagradas con las profanas?» 


\section{SEGUNDO AUTO: 1613-1614}

Pero el asunto no aparece en las actas capitulares de la catedral toledana hasta el año de 1614, convirtiéndose la prohibición de los autos en el principal tema de debate entre los canónigos. Algunos sucesos ocurridos en años anteriores pueden, sin embargo, arrojar alguna luz sobre los desencadenantes de este cambio. El 19 de diciembre de 1611, con ocasión de las honras de la reina Margarita, la ciudad se había considerado afrentada por el cabildo en cuestiones de etiqueta, por lo que abandonó el templo de forma extemporánea y se negó a asistir a la misa de honras que debía celebrarse al día siguiente. Desde entonces la corporación municipal quedó "como desterrada en esta santa yglesia sin hallarse en ella a fiestas ni processiones ${ }^{25}$. Las malas relaciones entre ambos cabildos se agudizaron cuando, el 20 de mayo de 1613, el corregidor y el alcalde mayor fueron excomulgados y se puso entredicho por razón de haber sacado un preso de los calabozos de la Inquisición. El entredicho fue alzado el 13 de julio, pero en octubre el vicario volvió a ponerlo por haber sacado la justicia real a un retraído de la iglesia ${ }^{26}$.

En otro orden de cosas, la celebración de la octava del Corpus de ese año fue un auténtico quebradero de cabeza para los canónigos. Los mayordomos solían contratar para los autos de la octava a la compañía que los había representado en Madrid el día del Corpus. Así se hizo aquel año con Riquelme, pero su espectáculo había tenido tal éxito en la corte que el propio rey lo reclamó para que representase la octava en San Lorenzo de El Escorial. Se hicieron todas las diligencias posibles para que Riquelme cumpliese el contrato, pero el capricho regio lo hizo imposible. Había que improvisar una solución para que la octava no quedara deslucida: Riquelme se ofreció a venir a Toledo el domingo posterior a la octava y otra compañía, la de Juan de Salazar, se prestó a suplirle representando otros autos, de los que incluso hizo muestra ante el cabildo en la víspera. No parece que los canónigos se mostrasen entusiasmados por la representación. Reconocieron, sí, que los autos eran buenos, pero no nuevos, como tampoco lo era el vestuario. Finalmente se consumó el fracaso de la fiesta y el cabildo, despechado, acordó que

«passada la otava del santísimo sacramento para cuya fiesta avía de ser la representación, no ay que tratar de que venga ni sea oydo Riquelme ni esta tarde representen los que ayer dieron la muestra..., y que de aquí adelante los señores Mayordomos que fueren no concierten las fiestas para la otava con el autor que representare en Madrid el día de Corpus Christi, porque no suceda otra vez lo que este año a sucedido» ${ }^{27}$.

\footnotetext{
25 ACT, $A C, 19-12-1611,20-12-1611,25-12-1611,22-3-1612$.

26 AC, 12-6-1613, 13-7-1613, 11-10-1613.

$27 A C, 8-6-1613,12-6-1613$ y $13-6-1613$.
} 
El Corpus del año 1614 fue, si cabe, más tormentoso. Los mayordomos habían concertado la representación de los autos con la compañía de Pedro de Valdés, pero vinieron dos alguaciles de corte para llevársela a la fiesta de Madrid, o al menos a algunos de sus componentes. El cabildo volvió a alarmarse y, después de agradecer al doctor Melgar por «estorvar que el pueblo no se alborotara contra los dichos alguaciles», solicitó la ayuda de la ciudad para hacer las diligencias oportunas en la corte. Al final fue nada menos el arzobispo quien llegó a un acuerdo con los comisarios de Madrid: Valdés podría representar en la catedral toledana a condición de que su primera actriz, Isabel Ana, actuase en la corte. Pero el prelado dejaba deslizar en su carta la insinuación de que «se comutase esta manera de fiesta en otra y se ahorrarían los dichos señores de las pesadumbres que cada año les dan sobre ella». El vicedeán recogió la sugerencia y propuso incluirla en el orden del día, pero el cabildo, de momento, rehusó hacerlo por mayoría.

Un nuevo roce con la ciudad ocurrido en la misma tarde del Corpus, el 29 de mayo, les haría pronto cambiar de opinión. En los primeros meses del año se había hecho lo posible por limar asperezas y olvidar el incidente de las honras regias. La corporación, incluso, se había mostrado dispuesta a participar en la fiesta del Sacramento con toda normalidad. La fatalidad, sin embargo, produjo un nuevo malentendido. Cuentan las actas capitulares que

«ayer tarde, aviendo representado el primer auto, fueron los señores Mayordomos a presentarle a la Ciudad, que suele estar en un tablado junto a las casas del señor Deán, y hallaron que ya la Ciudad se avía ydo sentida (según se decía) porque se avía cortado una soga del toldo que cubría el dicho tablado y desprendido una punta dél, lo qual sospechavan aver ordenado el cabildo desta santa Iglesia por hacer befa dellos, y que se avían ydo a la casa de su Ayuntamiento. Y allí el Corregidor avía mandado que un escrivano notificase a los representantes que no representasen el segundo auto al cabildo so pena de docientos açotes».

Rebasado el colmo de su paciencia, los canónigos ahora sí se mostraron dispuestos a reunirse "para tratar de mudar el gasto y fiesta de las representaciones en otra obra pía con que se sirva a nuestro Señor en la dicha fiesta sin tantos inconvenientes» ${ }^{28}$.

Tan interesante reunión se celebró todavía en caliente, el lunes 2 de junio. Acudieron 21 canónigos y nueve de ellos votaron de entrada para que se suprimiesen los autos. Encabezados por el doctor Luis de Tena, figuraban en este frente el doctor don Carlos Venero de Leiva, el vicedeán Álvaro de Villegas (canónigo magistral), José Pantoja, Diego de Morejón, Horacio Doria, Pedro Salazar de Mendoza, Cristóbal Ortiz, Miguel de Salazar, don Jerónimo de Miranda y Hernando Castellón, quien propuso que ni siquiera se representasen

28 AC, 12-5-1614, 14 mayo 1614, 30-5-1614. 
los autos de la octava de ese año ${ }^{29}$. A favor de la conservación de la tradición se manifestaron don Juan de Gómara, el maestrescuela don Gabriel Ortiz de Sotomayor, Gabriel Suárez de Toledo (arcediano de Madrid), el abad de San Vicente, don Juan Monsalve, el capellán mayor, el doctor Dionisio de Melgar (canónigo doctoral), don Antonio de Quiroga y don Juan de Marañón. Fue don Gabriel Ortiz, el maestrescuela, quien se erigió en portavoz de esta parcialidad. Alegó la antigüedad de esta forma de celebrar el Corpus en la iglesia de Toledo, señaló defectos de forma y advirtió que no podía tomarse resolución tan grave sin comunicarlo al arzobispo, requiriendo a sus compañeros para que no hiciesen novedad, en caso contrario de lo cual protestaba nulidad y anunciaba su intención de apelar. También mostró su oposición el doctor Melgar, quien, de forma sentida, declaró que las fiestas de representaciones eran conformes al derecho divino y canónico tanto como a las leyes civiles y constituciones sinodales del arzobispado; y que no era justo que, celebrándose en toda España con la asistencia de reyes y prelados, la Iglesia de Toledo no las hiciese. El canónigo manifestó su intención de apelar «ante Su Santidad y donde le convenga y protestava la nulidad y dar quenta a Su Magestad y su Consejo por ser cosa que toca al gobierno desta ciudad y consequentemente a otras muchas».

A pesar de ello, y por escasa mayoría, el cabildo adoptó el acuerdo de que «de aquí adelante el día de Corpus Chisti ni el de su otava no aya representaciones ni autos y que desta resolución se dé quenta a S.I. suplicando la confirme». Más igualada quedó la votación acerca de si en la inminente octava debían hacerse autos o, por el contrario, considerar el acuerdo ya en vigor. Sobre ello se impuso la decisión de una nueva mayoría según la cual, «pues esta santa Iglesia a usado a hacer las dichas representaciones y están prevenidas y hecha la costa para este año y la mayor parte del cabildo no viene en que se dexen de hacer, este año se hagan como suelen hacerse».

El enconado enfrentamiento con la ciudad, no obstante, no daría lugar a ello. El corregidor seguía empeñado en impedir las representaciones ante las casas del Deán y del Arcediano y en trasladarlas al Ayuntamiento, donde levantó el correspondiente tablado. Esa noticia motivó que el cabildo volviese a reunirse los días 3, 4, 5, jueves de la octava, y 6 de junio, y que se pidiese a Madrid una provisión real para que el corregidor no introdujera novedad alguna en los lugares de las representaciones. La víspera de la octava se tornó a votar, incluso, sobre la oportunidad de hacer los autos del día siguiente. El voto más locuaz fue el del canónigo Horacio Doria, uno de los partidarios de la supresión de los autos. En su parecer, las representaciones

29 Si bien de acuerdo en que no se hiciesen los autos en adelante, Jerónimo de Miranda defendió la opinión de que era mejor mantenerlos en la octava "porque no se atribuyese que se dexavan por miedo de pesadumbre que pudiese dar la ciudad». El debate puede seguirse en $A C, 2-$ 6-1614. 
«en quanto a las historias sagradas y actos heroicos que refieren eran buenas y por esta causa no se devían quitar, pero juntamente con las pías historias se juntavan entremeses ridículos y avía danças no honestas de mugeres y hombres farandoleros infames y cantares muy teatrales, lo qual todo estava prohibido por concilios y cánones y leyes y santos y doctores hazerse en las iglesias, quánto más delante del Santíssimo Sacramento descubierto, lo qual todo era ocasión de muchas risas, vozerías, indecencias y otros pecados».

A ello venían a añadirse ahora «las novedades que Toledo a intentado y ahora pretende, que es que los autos no se representen frontero de las casas del señor Deán y de las casas del señor Arcediano, sino que se hiciesen en la plaça del ayuntamiento». No había que perder de vista que el cabildo siempre había sido dueño de tales representaciones $\mathrm{y}$, por tanto, podía hacerlas donde quisiese, libertad que ahora el corregidor pretendía arrebatarle, causándole no sólo un daño en los alquileres de las casas desde cuyas ventanas se contemplaba la función, sino un grave perjuicio a la autoridad del Deán y del Arcediano. Concluía Doria que uniendo «el escrúpulo de conciencia con la novedad de Toledo, me parece que es forçoso dexar esta otava estas representaciones destos farandoleros y que no se representen». El capellán mayor llegó incluso a proponer que se llevase a la compañía de Valdés hasta un lugar de señorío, donde el corregidor no tuviese jurisdicción, y allí representase pagándole el cabildo lo estipulado. Aunque la mayoría volvió a estar a favor de la supresión, los votos de los indecisos acabaron sumándose a los de los contrarios y el resultado fue un empate, por lo que se acordó dejar en su fuerza la decisión tomada el lunes, aunque tratando por todos los medios de que el corregidor no se saliese con la suya. Tanta era la expectación y la preocupación del cabildo que volvió ese mismo día a reunirse en otras dos ocasiones, una a hora de vísperas y otra pasadas las seis. Así pudieron enterarse los canónigos de que había llegado por fin la provisión real, pero cuando el escribano fue a notificársela a la ciudad había sido maltratado por el alcalde mayor, lo que motivó el acuerdo de solicitar a la corte que viniese por la posta un escribano real para hacer la referida notificación con garantías de que fuera cumplida. El jueves de la octava hubo otras dos reuniones capitulares. Por la mañana predominó la moderación, advirtiéndose a capellanes, clerizones, ministriles y ministros que, aun en el caso de que la ciudad hiciese novedad, no «se alboroten ni causen escándalo alguno ni ofensa de Dios de palabra ni de obra en esta santa yglesia ni fuera della, porque los dichos señores no quieren llevarlo por armas, sino con toda paz seguir su derecho por vía de justicia»; pero en la tarde, cuando se hizo evidente que el corregidor no cedería, se pidió al vicario general que procediese con censuras contra la justicia de la ciudad porque impedían «el representar los autos esta tarde y avían mandado a los representantes so pena de quinientos ducados que no los representasen». El vicario, en efecto, no tardó en poner el entredicho.

En definitiva, los autos de la octava de 1614, que tanto trabajo dieron ese mismo año a la compañía de Angulo el Malo con que se topó don Quijote, no 
llegaron a ser representados en Toledo. El perjudicado Pedro de Valdés hizo una reclamación, pero no ablandó al cabildo, que por mayoría acordó que siguiese su justicia el caso de la octava, «pues no representó, y en quanto al día de corpus christi se le libren 1.300 reales para que se le paguen» ${ }^{30}$. En julio el cabildo consiguió una ejecutoria para que la ciudad no pudiese hacer novedades y en agosto una carta del Consejo Real instó a ambas corporaciones a mantener buena correspondencia, a cuyo tenor acordaron contestar los canónigos «mostrando mucho sentimiento de lo contenido en ella» ${ }^{31}$.

El tema de la representación de los autos no vuelve a aparecer en las actas capitulares hasta el día 20 de diciembre, día en que se desarrolló un larguísimo debate con la voluntad de zanjar definitivamente la cuestión. Los votos de los canónigos, razonados algunos de ellos por escrito, ocupan nada menos que cuarenta folios del libro de actas capitulares de ese año. Un debate tan prolijo proporciona naturalmente un gran cúmulo de información sobre los argumentos a favor o en contra de las representaciones de autos, sobre las alternativas que proponían sus detractores e incluso preciosos detalles de la forma en que se celebraba en la catedral la fiesta del Corpus.

Era opinión generalizada que la representación de autos en veneración del Santo Sacramento era una costumbre exclusiva de Castilla, pues en las iglesias de «los Reynos de Aragón, Navarra y Portugal no ay tal costumbre o abuso» (Jerónimo de Miranda); y que su antigüedad no era mucha, remontándose a sesenta años atrás, ya que «empeçó en el tiempo del Rey Don Philipe el segundo en la forma que agora se representa» ${ }^{32}$. Los partidarios de la supresión aluden en diferentes ocasiones a otras fiestas catedralicias que se habían prohibido tras una larga tradición, las del obispillo de san Nicolás y de los Inocentes, por haberse considerado indecentes ${ }^{33}$. Los contrarios, en cambio, procuraban diferenciar estas diversiones de las que se empleaban para festejar el Cuerpo de Cristo, cuyo «fin es honrar al santíssimo Sacramento con cantares y versos

$30 A C, 12-6-1614$. Para todo lo anterior, véanse las mismas $A C$ en las fechas que se indican en el texto.

$31 \quad A C, 4-7-1614$ y 5 y $7-8-1614$.

32 Afirmación de don Luis de Tena, que evidentemente se refiere a la prohibición del concilio toledano de que los clérigos representasen, lo que había obligado a recurrir a compañías profesionales. También el doctor Álvaro de Villegas recordó el reciente origen de estas representaciones.

33 Fue precisamente el concilio provincial de 1565 el que acabó definitivamente con esta fiesta «de locos», en que uno de los clerizones era elegido obispo el día de San Nicolás y presidía burlescas ceremonias y procesiones, hasta que un gran banquete ponía término al momentáneo «mundo al revés». Todavía en los libros de Obra y Fábrica de 1561 aparece una partida ordenando librar 7.480 mrs a un mercader «del gasto de la capa del obispillo de la fiesta de San Nicolás», o en 1564, en que se pagan $500 \mathrm{mrs}$ al clavero «de poner la nube para el día de San Nicolás para el obispillo». ACT, OF, libro 856, 24-1-1562, y libro 859, 15-2-1565, respectivamente. Sobre esta interesante fiesta véase el artículo de LOp OTín, $\mathrm{M}^{\mathrm{a}}$ José: «La catedral de Toledo, escenario de la fiesta bajomedieval», en Martínez-Burgos García, Palma, y Rodríguez GonzÁlez, Alfredo: La fiesta en el mundo hispánico, Cuenca, Ediciones de la Universidad de Castilla-La Mancha, 2004, pp. 213-243. 
hechos en su alabança, refiriendo historias sagradas y de otros santos, encareciendo la grandeza del misterio con hieroglíficos y otras figuras» (maestrescuela). Pero quien más datos nos aporta para el conocimiento de la forma en que se sucedían los elementos festivos es sin duda don Jerónimo de Miranda, que de esa guisa quería aportar elementos para demostrar la impropiedad de los autos. Según su testimonio, «la fiesta comiença en las vísperas de aquel día». Justo antes de que en el coro los canónigos comenzasen el rezo de completas entraba en él «tanto ruydo y vocería con las danças que duran casi tanto como ellas... y todo viene a parar en tres o quatro danças muy ordinarias y desonadas muy vulgares y profanas, indignas de aquel lugar». En la mañana, muy temprano, se tocaba a prima, que se decía «con mucha priessa y ruydo de los carros que están a la puerta del choro para representar, lo qual hazen por espacio de dos o tres horas, las primeras y mejores del día», tiempo en que resulta imposible decir ni oír misa en cualquier parte del templo por el mucho ruido que hay. Hasta que no acaban los autos no puede empezar la misa mayor, a la que asisten pocos prebendados, «porque unos van a decir missa y otros a almorçar, en lo qual ay también indecencia atravesando platos por la iglessia y comiendo dentro del ámbito della». Al término de la misa, ya cerca de las once, sale al fin la procesión,

«y aunque con muy grande autoridad, por ser ya tarde, va con gran priesa, y con todo eso se buelve muy tarde, que es ya la una. De allí a poco espacio se tañe a vísperas, las quales se dizen con priesa y mucho ruydo por razón de los autos que comiençan luego, y duran otras dos o tres oras. $\mathrm{Y}$ acavado esto, que está muy tarde y casi noche, se encierra el Santíssimo Sacramento».

De este modo, concluye Miranda, las vanidades y profanidades de los autos se erigen en la esencia de las fiestas, "diciendo que an sido buenas o malas según lo an sido los autos». Aunque es evidente la intención de caricaturizar algunos detalles, ésta es sin duda una de las mejores descripciones de la fiesta del Corpus en estos últimos años en que los autos aún estaban integrados en el ceremonial catedralicio.

Los argumentos utilizados por unos y otros se repiten y recurren a las mismas fuentes, que interpretan de distinto modo. Quienes muestran mayor interés en documentarse son los contrarios a las representaciones, que enarbolan hasta apabullar las decisiones de concilios y sínodos, la doctrina de santos y téologos, y las sentencias de san Agustín, Tertuliano, san Juan Crisóstomo y santo Tomás, o autoridades como Silvestre y Cayetano, o incluso autores recientes como Suárez o el mismo padre Mariana.

Para la facción rigorista del cabildo, defendida por don Luis de Tena, don Álvaro de Villegas, don Horacio Doria y don Jerónimo de Miranda, las representaciones de autos eran una costumbre local nada conforme con la Iglesia de Roma; y así como Toledo hubo de renunciar a su rito mozárabe, que tampoco lo era, se debía ahora terminar con esta anomalía. Aun cuando en sí mismos no fueran malos, los autos adquirían el carácter de pecaminosos cuando se hacían 
en lugares sagrados, por cuanto introducían en ellos la profanidad, la lascivia y la indecencia ${ }^{34}$. Eran absolutamente superfluos, ocasionaban muchos gastos y distraían a los fieles de la verdadera devoción con «el ruydo, voces y gritos descompuestos que se dan en el cuerpo de la iglesia», siendo causa además de que los oficios divinos se dijesen «con grande priessa y acceleración por ir a oyr los autos» (Tena). Y en definitiva, los representantes eran gente baja, vil e infame, impropia para representar los misterios divinos.

«Y qué devoción podrá causar a nadie oír las lágrimas de san Pedro representadas por un hombre notoriamente viciosso o infame y las de la Magdalena por una mujer de mala vida (o que lo a sido)? Y lo que peor es y más ofende, que estas mismas personas representen la de nuestro Señor y su santíssima Madre, las mismas que en el mismo theatro y comedia an representado o representarán la de un rufián y una ramera o cosa poco menos obscena?» (Miranda).

Los enemigos de los autos no se limitan en sus votos a pedir su supresión de las fiestas del Corpus y de su octava; algunos, conscientes de que de ese modo quedarían deslucidas, se atreven a ofrecer alternativas. El parecer de Villegas era que «lo que se avía de gastar en comedias, y dar a gente vil y infame, se distribuya en limosnas, y será sin duda nuestro Señor más bien servido y el pueblo edificado y los pobres socorridos»; Luis de Tena proponía «hazer otros exercicios de mayor honra y gloria para la dicha festividad poniendo carteles con varios premios para que los ingenios de los Poetas y oradores se exercitasen en alabança del Santíssimo Sacramento con varios y diversos géneros de composturas»; Doria creía bastante para atraer la curiosidad popular los motetes que de forma solemne entonaba la capilla musical, «y sin ninguna duda que no faltará persona alguna de Toledo a esta fiesta, aunque no aya comedias, con que aya algunas cossas devotas que la capilla cante»; y Miranda ideaba sustituir las danzas por el canto de villancicos, "como se haze la noche de Navidad, y quando ubiese de haver alguna dança fuese solamente de los colegiales infantes y seyses». Si acaso, continuaba este canónigo en un mar de dudas sobre los resultados, cabría una representación, siempre que hubiesen acabado vísperas y completas y que fuese grave y devota, «hecha por clerizones y otras personas honestas»; pero recordando en seguida la prohibición de la vieja costumbre, concluía:

«Esto digo en casso que pareciese conviniente hazerse alguna representación, que por mejor tendría que no la ubiese, pues el concilio Toledano que se celebró

34 En ellos se mezclan «entremeses, bayles y cantos lascivos, cossas de chocarrería y que mueven a risa, y otras profanas y indecentes» (Álvaro de Villegas); «y quitar estas cossas profanas es quitar la occasión a los herejes de que no tengan que poner falta en el modo con que celebramos esta fiesta» (Miranda). Álvaro de Villegas señalaba la indecencia que suponía «que se quede el Santíssimo Sacramento solo, y los que están entre los dos choros le buelvan las espaldas por bolver el rostro a los faranduleros». 
el año de 1561 (sic) tuvo por inconviniente y prohibió que los clérigos representasen estas comedias que solían hazer, lo qual fue ocasión de que se introduxese el abuso y inconviniente en que ahora se está de que las represente esta gente».

En lo que todos coincidían era en que la supresión de los autos debía ir en beneficio de la solemnidad de la procesión, auténtica esencia de la fiesta del Corpus. «La procesión particular en esta fiesta -pedía Villegas-, sea ahora competente y con el espacio, gravedad y devoción que se deve a la presencia Real de Christo nuestro Señor» ${ }^{35}$.

La voz cantante de los partidarios de los autos fue una vez más la del maestrescuela, quien utilizó en su parlamento todos los argumentos posibles. El teatro y las danzas, lejos de ser irreverentes, no eran sino una muestra de humildad y regocijo, de manifestación de la alegría interior, como la de David cuando bailando delante del arca «juzgó por acto de humildad hazerse loco delante del Señor»; y este uso, contra lo que defendían los adversarios, era muy antiguo y estaba generalizado entre «todas las naciones del mundo». Dejando de lado lo lascivo, chocarrero e indecente, que obviamente se debía extirpar, ninguna autoridad había condenado las representaciones en sí mismas, y lejos de ser perjudiciales ayudaban a mover a devoción, pues

«por la flaqueça y miseria de la naturaleza humana, aun para entrar en las cossas de devoción es menester ayudarla con actos que, exercitándoles en el bien, deleyten los sentidos como puertas del alma, y por esto vemos que la Iglesia Cathólica usa de muchos actos exteriores, como son los adornos en los templos y en las processiones y otras semejantes, para que con la vista destas demonstraciones de respeto exterior se levante el pensamiento a entender la estimación que interiormente se debe hazer a las cosas sagradas de Dios y de sus santos, y amarlas y desearlas».

También rompía una lanza el maestrescuela en defensa de los actores, quienes no eran seres infames, sino personas normales a las que se concedía sepultura eclesiástica y eran admitidas a los sacramentos, a testificaciones y, lo que era de más peso, a las órdenes sagradas, como un tal Navarro que «en una comedia de san Francisco que representó el mismo santo, saliendo compungido della, se metió frayle, y lo mismo se refiere de otros de su proffesión». En consecuencia, su voto era favorable al mantenimiento de las representaciones,

«evitando los entremeses y bayles impúdicos, y que no se hagan en los dichos autos ni se representen las figuras de Christo nuestro Señor ni de persona de la Santíssima Trinidad ni de nuestra Señora ni del summo Pontífice, como ya está

35 Y Miranda proponía que «el día de la fiesta se dijesen todas las horas con el espacio y solemnidad que esta santa Iglesia acostumbra y que a hora competente saliesse la procesión, en la qual ubiesse dos o tres estaciones donde la custodia del Santíssimo Sacramento parase, y se hiziessen altares con sumptuosidad, y cesaría el inconviniente de yr tan apriessa y como rebentando los que llevan la custodia, y la procesión se acavaría a hora competente». 
prohibido otras vezes, y que, como se mandó el año de 1601 o 602, las muestras se hagan delante de los señores mayordomos y otros dos comisarios nombrados por el cabildo.., los quales miren todo lo indecente e inhonesto y lo quiten y no consientan hazer, para lo qual se haga la muestra veynte días antes de la fiesta».

En todo caso, antes de tomar decisión tan grave, era preceptivo consultar a universidades y letrados, así como al Rey y al Arzobispo.

El ardor del maestrescuela no logró impedir que sus contrarios ganasen la votación con el resultado de doce a siete, con dos abstenciones ${ }^{36}$; "y ansí votado, pasó por mayor parte que no se representasen autos en esta Santa Iglesia en las fiestas del Santíssimo Sacramento y su octava, y que antes de practicar esta resolución se dé quenta della a S.I.» Sólo faltaba, pues, la ratificación del arzobispo; y fue ésta la última instancia a la que se agarraron los perdedores para presionar y conseguir un vuelco en la situación, razón por la cual las discusiones sobre los autos volverán a proliferar a lo largo de las actas capitulares del año siguiente de 1615 .

\section{TERCER AUTO: 1615}

El año comenzó con los intentos de lograr una concordia duradera con la ciudad, pero era condición que el cabildo se pronunciara sobre el nuevo lugar que la corporación pedía para ver los autos, en caso de que se siguiesen haciendo. Porque, de lo contrario, el Ayuntamiento se comprometía a hacerlos a su costa e insinuaba que la procesión debería esperar a que hubiesen terminado las representaciones. De ello podrían resultar, notó el canónigo obrero Garay, algunos inconvenientes, «que convendría tratar si son de más peso que los que se ofrecieron quando se acordó que no ubiese auctos en esta Santa Iglesia» ${ }^{37}$. El cabildo no dio, por ello, su brazo a torcer y se ratificó en su decisión. Pero una carta del arzobispo Sandoval, leída el 25 de febrero, les llenó de estupefacción y dio un giro inesperado a una situación que ya parecía clara.

"Que los comisarios de los autos y danças se encarguen mucho de remediar los inconvenientes y daños, y se prevenga lo necesario para que el Santíssimo Sacramento esté con la decencia, autoridad y acompañamiento necesario. Que los autos y danças se hagan detrás del coro. Con lo qual, y lo demás que el cabildo acordare para prevenir los acompañamientos y daños, escribe que, si no se escusa-

36 Votaron por la supresión: el arcediano de Toledo, arcediano de Talavera, Luis de Tena, Álvaro de Villegas, Horacio Doria, Hernando Castellón, doctor Aristi, Cristóbal Ortiz, Jerónimo de Miranda, Antonio Fernández Portocarrero, José Pantoja y Juan de Monsalve. Y en favor de la conservación de los autos: el maestrescuela, el abad de San Vicente, doctor Melgar, arcediano de Madrid, licenciado Garay, Pedro Ocón y Antonio de Quiroga. Se abstuvieron, o suspendieron su voto, Juan de Gómara y Juan de Silva.

37 AC, 12-1-1615. 
ren este año, tendrá de muy buena gana la opinión que el cabildo le escribió, ansí por consolarle y servirle como porque verá la necesidad forçosa de la novedad, aunque le lastimará la pena y desconsuelo de la ciudad y del pueblo».

De forma inesperada el prelado había indultado al toro, o al menos había concedido una moratoria. Frente a la satisfacción de algunos, el disgusto ganó a los contrarios, que volvieron a imponer su mayoría para responder a Su Ilustrísima que con los autos «no se puede hazer en conciencia ni con decencia el culto divino». La minoría se defendió con votos particulares y el 28 de marzo el maestrescuela leyó un requerimiento, firmado por otros cinco canónigos ${ }^{38}$, en que defendía la virtud que tenían los autos «para despertar con la representación viva la devoción de los fieles a tan alto y soberano misterio» y desglosaba una serie de razones por las que debían seguir haciéndose. Para mejor fundarlas hacía Ortiz un interesante recorrido por la historia de estas representaciones que, según afirmaba, venían de tiempo inmemorial. Recordó que en un principio se acostumbraba hacerlas "por clérigos y personas de la dicha Santa Iglesia, hasta que, teniendo esto por indecente, el concilio toledano que se celebró el año de 1565 prohivió que los clérigos no pudiessen representar, teniendo por más decente que lo hiciessen por otras personas que lo han por officio, lo qual se ha guardado inviolablemente desde entonces acá». El concilio, pues, no las había reprobado en sí mismas; por el contrario, las permitía siempre que se hiciesen «con la moderación y examen que se debe». Los maestros y doctores de la Universidad de Salamanca, por su parte, habían desechado cualquier escrúpulo, conviniendo «en que, cesando las cossas impúdicas e indecentes, se pueden hazer las dichas representaciones». También había que tener en cuenta los inconvenientes en caso de que fuera la ciudad la organizadora de las representaciones, situación en la que sin duda se reproducirían las desavenencias y altercados entre ambos cabildos ${ }^{39}$. Y finalizaba con un argumento inédito: el pueblo (sic) tenía el derecho adquirido de que se hiciesen las representaciones,

«sin que se pueda decir que esta hacienda es del cabildo y que como dueño puede hazer della lo que quisiere, porque es cossa llana y asentada en derecho que el pueblo puede prescribir en la hacienda eclesiástica a que della se haga tal o tal gasto que se ha acostumbrado, como en este caso, del qual no puede ser privado si no es por sentencia».

38 Ibidem, 5-3-1615 y 28-3-1615. Eran éstos el tesorero don Diego Morejón de Ribera, don Francisco de Monsalve (abad de San Vicente), el doctor Dionisio de Melgar, don Juan de Gómara y don Antonio de Quiroga.

39 Ibidem. «... porque la dicha Ciudad a de querer asistir a las dichas representaciones... y esta Santa Iglesia a de querer salir con su procesión sin orden a las dichas representaciones ni aguardar a la dicha Ciudad, lo qual no dará lugar a que los officios y otras cofradías de personas seglares salgan a la dicha procesión hasta que el Alcalde mayor con el escrivano del secreto los ordenen y llamen como siempre an acostumbrado a hacerlo, y ansi mismo an de pedir que no se tañan las campanas mientras se representare», lo que ocasionaría escándalo en vez de devoción. 
Los canónigos encabezados por el maestrescuela se comprometían, en fin, a concertar los autos del Corpus, a someterlos a una muestra previa a la que asistirían los teólogos del cabildo y otros ocho de la ciudad, y a pagar de su bolsillo lo estipulado a los representantes en caso de que las obras fueran finalmente censuradas.

Volvieron a alzarse voces encontradas sobre si los firmantes de este requerimienro podían ser jueces en lo que proponían, es decir, si debían participar en la votación, cosa que al final consiguieron, y con ello la victoria, puesto que «pasó por mayor parte, en que se contaron los votos de los dichos señores que requirieron que aya autos, y se responda a la carta que sobre esto escrivió su S.I. que se obedece lo que manda» ${ }^{40}$.

En sólo tres meses, así, la situación había dado un vuelco. Los autos continuarían contribuyendo como siempre al regocijo propio de la fiesta del Corpus, con la única diferencia de que el lugar de representación era desplazado desde el crucero al trascoro. Con ello los tablados también deberían mudar su lugar,

«de manera que en una propia hilera estén ambas comunidades, la Iglesia a mano derecha y la Ciudad a la izquierda, de forma que lo divida una tabla de por medio, viniéndose a juntar allí ambas cabeças, y estendiéndose cada cuerpo de su comunidad en lo restante de su tablado, y dexando al Santíssimo Sacramento en sus andas en la capilla mayor, acompañando algunas personas que allí estén belando».

Pues bien, este cambio significaba modificar todo el protocolo y también dio lugar a una apasionada polémica. El 11 de abril don Luis de Tena presentó un memorial en el que analizaba las ventajas e inconvenientes de esta novedad. Entre las primeras se contaba el que se acabaría así con la indecencia que suponía dar la espalda al Santísimo, unos por ver los autos y otros por representarlos; también se satisfacía el deseo de la corporación municipal de que su tablado estuviese bajo techo y no como el que había tenido, expuesto a las inclemencias del tiempo y «a que se cayga el toldo, como otra vez a sucedido; y fuera desto se aorra una hora de tiempo oyendo los autos juntos Yglessia y Ciudad, y así se podrá hazer el oficio más de espacio y la procesión con mayor sosiego»; y las campanas podrían, además, tañerse a sus horas, sin temor a que impidiesen a la Ciudad escuchar su representación.

Sin embargo, los inconvenientes le parecían infinitamente mayores que las ventajas. Era el primero que se faltaba a la solemnidad exigida por una fiesta dedicada al Santísimo Sacramento, razón por la cual la celebración se había hecho siempre en su presencia; si las representaciones no se hacían delante de la custodia, era evidente que perdían todo su sentido. Por otro lado, se planteaban gravísimos problemas de protocolo. Siendo reconocido el rango superior del estado eclesiástico respecto del secular, y correspondiéndole por ello el pri-

40 AC, 31-3-1615. 
mer lugar, la nueva disposición venía a igualarlos, «y así vendría a ceder en diminución de la autoridad desta Santa Iglesia el querérsele igualar el estado secular». La preeminencia eclesiástica también era puesta de relieve en el hecho de que los autos se representasen primero ante el cabildo, y sólo después se ofreciesen a la ciudad. Era previsible que el corregidor exigiera, como lo había hecho en otras ceremonias, que se le pusiese almohada que no tenía el deán, lo cual también iría en menoscabo de sus privilegios. Se preguntaba Tena por qué la Primada de las Españas había de perder sus preeminencias

«so color de una paz tan quebradiça que por averse cortado casualmente una cuerda de un toldo, levantó la borrasca que el año passado se vio, haciendo tan notable violencia qual fue prender los representantes para que, estando todo a punto y el cabildo junto, y enviados comisarios para hacer requerimientos al corregidor, se impidiesse la representación con tan grande nota y publicidad».

Y Tena proponía que, perdiéndose más de lo que se podía ganar con la mudanza, se mantuviesen los autos en el escenario acostumbrado o se introdujesen cambios mínimos,

«qual sería que, estándose el tablado de la Iglessia adonde suele, en los arcos de enfrente se hiziese otro tablado para la Ciudad, de manera que los representantes tubiessen los rostros hacia la puerta de la Chapinería y las espaldas a la puerta de los Leones, con lo qual cesaría el tener las espaldas a el Santíssimo Sacramento y la descomodidad que la Ciudad alega del tablado que ahora tiene en la calle».

Efectuada la votación, la propuesta de Tena fue rechazada y se acordó que las representaciones se hicieran en el trascoro, donde había indicado el arzobispo, y en una única función que verían juntos cabildo y ciudad.

«que en la nave grande del trascoro, arrimado a él, se haga un tablado grande que tome de pilar a pilar en los primeros pilares de ancho y de largo hasta la pared del trascoro, el qual se a de dividir igualmente por medio con tablas de arriva abajo, y en la parte de la mano derecha estén los señores Deán y Cabildo, y en la parte de la mano izquierda esté la Ciudad, de tal manera que las dos primeras personas más llegadas a la división sean y estén el señor Deán en la parte de la mano derecha y el Corregidor en la parte de la mano izquierda, y ansí consecutivamente los demás por sus antigüedades en la una y otra parte».

Cada una de las secciones debía tener su puerta independiente para evitar mezclas inconvenientes entre ambos cuerpos. Y delante de este tablado, más o menos de su tamaño, se dispondrían «los carros llanos, y los carros en que viniesen los farsantes y hizieren apariencias an de quedar de manera que no estorven la vista a los señores Deán y Cabildo ni a la Ciudad, y los farsantes se an de poner en medio igualmente». 
Se acordó también que se diese la casa de comedias a la compañía con la que se concertasen los autos para que representase en Toledo desde la Pascua de Resurrección, probablemente para controlar los ensayos y para asegurarse de que diese la muestra con la antelación debida. Las últimas discusiones se allanaron con una votación en la que pasó por mayoría «que la Ciudad aya de estar y esté en su parte del dicho tablado quando se acave la hora de Prima para que luego se comiencen las representaciones como es costumbre, sin que los dichos señores ayan de esperar a la Ciudad».

Los mayordomos de aquel año, partidarios de la supresión, habían pedido ser exonerados de la organización de la fiesta, que fue encomendada al maestrescuela y al canónigo obrero. El 18 de abril comunicaron que ya habían concertado los autos del Corpus con la compañía de Riquelme, que también había participado el año anterior. Don Carlos Venero de Leiva, uno de los mayordomos dimisionarios, criticó esta elección y advirtió de que no se fiaba de Riquelme, a quien tenía por «hombre descuydado», y contó la ocasión en que

«estuvo el Cabildo aguardándole una hora para que viniesse a representar y fue menester que el señor Don Francisco de Ydiáquez, Mayordomo que con su merced era, fuesse con su vastón a sacar de la cama al dicho Riquelme quando ya era hora de representar» ${ }^{41}$.

No parece, sin embargo, que se presagiasen incidentes en la celebración de la fiesta. Por el contrario, en los días cercanos a ella, se extrae de las actas la satisfacción del cabildo por que los oficios pudieran hacerse con mayor tranquilidad que otros años, habida cuenta del tiempo que se ahorraba en no tener que llevar los autos a la ciudad y esperar a que finalizasen para dar salida a la procesión. Podemos imaginar que el espacio catedralicio fue compartido por dos actos simultáneos: mientras en el trascoro se desarrollaba la representación, en el altar mayor, donde estaba expuesto el Santo Sacramento, un grupo de prebendados, racioneros y capellanes cantaron salmos ante la custodia, y lo mismo se hizo eel día de la octava por la tarde desde las tres asta acavados los autos» ${ }^{42}$. En los libros de obra y fábrica de 1615 constan los libramientos que se hicieron a Riquelme por los autos del Corpus y a Tomás Fernández por los de la octava, así como al maestro Valdivieso por dos autos que compuso, al pintor Bartolomé del Río por aderezar los carros para la fiesta y a Gaspar de Hermosa por un memorial de invenciones ${ }^{43}$. Algunas cosas debieron de salir mal, no obstante, a juzgar por una discusión que consta en las actas del año siguiente. Según lo que se deduce de ella, Riquelme no dio la muestra de sus autos hasta la víspera de la Trinidad, siendo así que estaba obligado a darla en la Ascensión; y, al parecer, tampoco cumplió de forma satisfactoria en las fiestas de la octava que estuvieron a su cargo ${ }^{44}$.

\footnotetext{
41 AC, 4-4-1615 y $18-4-1615$.

$42 A C, 2-5-1615$ y $7-5-1615$.

43 ACT, $O F$, año 1615 y 1615 bis.

44 AC, 13-8-1616.
} 


\section{CUARTO AUTO: 1616-1617}

De todos modos las cosas parecían haberse enderezado y 1616 comenzó con el cabildo instalado en un cierto consenso que, sin embargo, no tardaría en mostrarse precario. Los canónigos parecían entonces más interesados en la inminente inauguración de la nueva capilla del Sagrario auspiciada por Sandoval y Rojas, con la consiguiente traslación de la imagen, lo cual debía realizarse en medio de grandes festejos y demostraciones de alegría. Los siete días de la octava se amenizarían con otros tantos certámenes o espectáculos:

«Que el primero podrá ser de música a la guitarra, el segundo de dançar, el tercero de música de un instrumento de facistor, el quarto del voces del coro, el quinto de poessía castellana, el sexto de latín, el séptimo alguna comedia hecha a propósito y encomendada a muy buenos farsantes con premios mui buenos para todos estos certámines. El octavo día, después de aver avido como los demás missa y sermón, a la tarde se haga una solemnísima procesión con la imagen, sacándola por donde va la del Santíssimo Sacramento o la del domingo de quasimodo, y que para esto se convoquen curas, cruces y pendones, o de todo el Arçobispado o de la comarca, y a la vuelta se haga la colocación de la santíssima ymagen en su lugar»45.

Entre las diversiones, pues, no faltaban las comedias, aunque algunos canónigos no dejaron de pasar la ocasión para mostrar sus ya conocidas reticencias hacia el arte de Talía. Don Andrés de Aristi opinó que debían hacerse fuera de la iglesia «y de cossas muy honestas»; otros cinco canónigos encabezados por Villegas y Doria «fueron de parecer que ni aun fuera de la yglesia aya representaciones». Al final se optó por que las hubiera con tal de que «no sean dentro de la yglesia, sino en algún tablado que se haga delante de las casas de V.S.I. y por la tarde» ${ }^{46}$.

Pero también los autos del Corpus trajeron este año no pocos quebraderos de cabeza al cada vez más susceptible cabildo. El 23 de abril informó don Lucas de Silva de que el autor concertado para hacer las fiestas estaba retenido en Madrid. Los canónigos no perdieron esta vez un ápice de su dignidad y acordaron que no se hiciese diligencia alguna para que los farsantes vinieran, "porque no conviene a la grandeza de la Iglesia tratar de representantes», aunque teniendo buen cuidado en recuperar los 2.000 reales que se les habían librado. Lo único que pudieron hacer los faranduleros es ofrecerse a representar en la octava, pero el cabildo permaneció inflexible, pues le pareció «cosa de aldea» hacer representaciones ese día no habíendolas tenido el día principal. En consecuencia, acordó que no hubiese autos en la octava. Y en cuanto al día del Corpus, propuso el arcediano de Talavera que,

\footnotetext{
45 AC, 18-2-1616.

46 AC, ibidem.
} 
«aviendo visto cómo se hicieron el año pasado, y considerado la devoción y mayor concurso del Pueblo que ubo el día de Corpus Christi deste presente año en la procesión y en los oficios divinos, que todo se hizo con más solemnidad y frequencia de los fieles por no aver avido representaciones que los entretubiesen para no acudir a la dicha procesión y oficios, le parecía de mucho servicio de Dios executar lo acordado que no aya más representaciones de aquí adelante» ${ }^{47}$.

El maestrescuela, que se las había prometido muy felices, reaccionó a la desesperada, protestando de que estas cosas eran demasiado importantes para depender de un voto más o menos, y que para introducir novedad era preceptivo reunir a todo el cabildo y volver a pedir licencia al arzobispo. El acuerdo mayoritario fue el de convocar un cabildo para tratar sobre la propuesta del arcediano y proveer en consecuencia ${ }^{48}$. De nuevo las espadas estaban en alto y las dos facciones se recomponían, si bien los preparativos de la fiesta de traslación de la Virgen del Sagrario, fijada finalmente para el 30 de octubre, mantuvieron bien ocupado al cabildo, que no volvió a tratar del asunto hasta el año siguiente.

Los últimos autos del Corpus que se representaron en el interior de la catedral de Toledo fueron, así, los de 1615, pero el día en que oficial y definitivamente fueron suprimidos, acabándose así con una arraigada tradición de siglos, fue el 14 de enero de 1617. Fue entonces cuando el arcediano de Talavera presentó su decisiva proposición, del tenor siguiente:

«dixo que por experiencia se halla que no ay cuydado que baste para quitar del todo lo obsceno y torpe destas representaciones, y porque es indecente e indigna cosa que farsantes viles y infames representen la persona de nuestro Señor Jesuchristo y de su santíssima Madre y de algún otro santo, y luego dancen torpemente en el teatro, y porque las dichas representaciones usurpan y quitan el tiempo devido a la procesión solemne del Santíssimo Sacramento y gastan las horas que se avían de emplear en celebrar las divinas con la decencia y Magestad religiosa que en solemnidades tales se acostumbra, y por seguir el exemplo de la santa Yglessia Romana, y cumplir puntualmente la forma de celebrar tan gran fiesta señalada por el santo Concilio Tridentino y la doctrina de los santos Padres y Teólogos que abominan tales representaciones y representantes y los juzgan por indignos de traerlos a celebrar misterios divinos, y por otras raçones referidas en los actos capitulares desta materia, especialmente los del 20 de Deciembre de 1614 , su voto es que no aya tales representaciones de farsantes en el día y octava de Corpus Christi este presente año ni en los venideros perpetuamente».

47 En el libro de $O F$ correspondientes a 1616 constan libramientos por los autos del Corpus a Pedro Cerezo, y por los de la octava a Pedro Cebrián. También se libraron 50 reales al licenciado Sebastián de León para acabarle de pagar dos autos del día del Corpus.

48 Para todo lo anterior, véanse las $A C$ de 23-4-1616, 1-6-1616, 3-6-1616 y 6-6-1616, día en que el arcediano de Talavera hizo su propuesta y se acordó tratarla en un próximo cabildo. 
El arcediano se vio esta vez apoyado por una aplastante mayoría de trece votos contra dos ${ }^{49}$, aprovechando la inasistencia del maestrescuela y de sus principales seguidores, algunos de los cuales habían fallecido o abandonado su canonjía ${ }^{50}$. Horacio Doria remachó el acuerdo pidiendo que, para que no pudiera ser revocado esta vez, se suplicase a Su Santidad lo confirmase, y aunque Juan de Monsalve alegó tímidamente la conveniencia de tratar en otro cabildo esta nueva propuesta, fue opinión de la mayoría que no era necesario un nuevo llamamiento. La facción rigorista había triunfado al fin y los autos del Corpus en la catedral pasaron a ser historia.

De la mentalidad postridentina opuesta a todo asomo de profanidad da idea también otra discusión que, en torno a la fiesta del Sacramento, se suscitó este año. Era la costumbre ofrecer al Santísimo una sesión musical que gradualmente fue adquiriendo un sesgo marcadamente popular. Los canónigos salieron al paso de esta indeseable desviación, prohibiendo "que se toque instrumento que no sea eclesiástico o ordinario del coro, y se cante al encerrar el Santíssimo Sacramento un villancico y motetes, y a nona otro villancico y motetes, con tal de que sean en lengua castellana vistos y aprobados». Jerónimo de Miranda fue más allá, consciente de la mucha «impropiedad y indecencia, así en la composición de los villancicos que se cantan como en la composición de la música y tonadas dellos». So capa de devoción, los villancicos eran de suyo profanos por mucho que se tratara de disfrazarlos acomodándolos a lo divino, lo cual era otra indecencia. Proponía, pues, que se proscribiesen los romances y villancicos en lengua vulgar y sólo se permitiesen los himnos y antífonas que la Iglesia tenía ordenados. Con ello cesarían las indecencias «que avía en el concurso de gente que avía antes de nona, que parece tenía tanta y más parte de entretenimiento que de devoción, cantando y tañendo instrumentos que de suyo son profanos y que no los usa la Yglesia» ${ }^{51}$.

Otra anécdota que revela el nerviosismo de los canónigos se produjo con ocasión del experimento con el que se quiso innovar en la procesión de aquel año, cuando se decidió que la custodia no fuese cargada a hombros sino llevada en un carro, «atento a que por el gran peso de la plata y oro de ella, la llevan sacerdotes con tanto trabajo que apenas dan paso con decencia, sin corriendo

49 Votaron con el arcediano: Cebrián Muñoz, Carlos Venero de Leiva, Álvaro de Villegas, Horacio Doria, Hernando Castellón, Pedro Salazar de Mendoza, Andrés de Aristi, Cristóbal Ortiz, Miguel de Salazar, Jerónimo de Miranda, Francisco de Idiáquez y Antonio Fernández Portocarrero. En contra votaron solamente Juan de Monsalve y Francisco de Monsalve, abad de San Vicente.

so Ignoro las razones de la inasistencia del maestrescuela don Gabriel Ortiz de Sotomayor, aunque quizá pueda explicarla su nombramiento como capellán mayor del monasterio real de la Encarnación de Madrid. De los que, en diciembre de 1614, se habían mostrado partidarios de los autos, Dionisio de Melgar había fallecido, Antonio de Quiroga se encontraba fuera de Toledo curándose de una enfermedad y Pedro Ocón mermado por su edad y sus achaques, según testimonian las $A C$ de 27-5-1617.

51 AC, 24-5-1617. 
un poco, y luego dando voces los unos a los otros para que paren». Pero en una ciudad tan arriscada como Toledo tampoco era fácil este procedimiento. Resultando imposible que el carro bajase la cuesta que iba de la iglesia de la Compañía a las casas arzobispales, se propuso desviar la procesión por delante de la cárcel hacia la iglesia de San Salvador, a lo que don Juan de Monsalve se opuso con un argumento insólito:

«atento que a oydo decir ser cierto que en años pasados algunos malos Christianos tenían minado aquel sitio para con pólvora bolar las personas que llevasen al Santíssimo Sacramento, y se mandó entonces (aviéndose descubierto la trayción milagrosamente) que no pase la procesión de allí adelante por aquel sitio» ${ }^{2}$.

En cuanto a los autos, el Ayuntamiento se mostró muy preocupado y envió varias embajadas al cabildo hasta convencerse de su firme resolución. Entonces apeló al Consejo Real lamentando que se hubiesen dejado de hacer las representaciones en la ciudad que había instituido la fiesta y que servía de ejemplo a todas las del reino. La actitud de la Santa Iglesia no tenía justificación, máxime cuando dicha fiesta «estava dotada en la Mesa Capitular y en la renta de la obra». Toledo obtuvo una provisión real que conminaba al cabildo a no hacer novedad en su obligación, pero los canónigos, indignados, acordaron escribir al presidente del Consejo probando la incerteza de lo contenido en la provisión ${ }^{53}$. Juan Belluga, delegado de la ciudad en la corte, escribió al Ayuntamiento refiriendo que el presidente le había reconocido que no podía apremiar al cabildo a que hiciese la fiesta, y le había aconsejado que la ciudad la tomase a su cargo; ya se vería de qué manera conseguir el dinero, para lo cual el consejo daría su licencia sin duda ${ }^{54}$. El regimiento se apresuró a pedir facultad para obtener 1.500 ducados anuales para las fiestas cargando medio real en cada pieza de telillas de cualquier suerte. Tanto apremió Belluga al Consejo que, habiéndose apartado ya sus salas, volvieron a juntarse para conceder a Toledo lo que pedía sólo por ese año. La ciudad recibió la notificación con euforia y el corregidor no tardó en nombrar comisarios de la fiesta a dos regidores y dos jurados, para que viesen

«el modo como se an de hazer las dichas representaciones y dónde se a de representar y de dónde se a de pagar lo que costare... e concierten con el autor... lo

52 AC, 4-4-1617. ¿Resonancias tardías de la llamada «conspiración de la pólvora» de 1605 en el parlamento inglés? En cuanto al nuevo sistema de procesionar la custodia, no debió de funcionar bien, pues en las $A C$ de 26-5-1617 se acordó que «pasada esta octava, no sea jamás llevada en carro la custodia del Santíssimo Sacramento».

53 AC, 21-2-1617.

54 ARCHIVO MUNICIPAL DE TOLEDO (en adelante AMT), Libro de Acuerdos Municipales (en adelante L.A.), $\mathrm{n}^{\circ} 37,13-3-1617$. Curiosamente aseguró Belluga al presidente del Consejo que «la principal causa que movía al Cabildo avía sido averle faltado aquella representante con que pararon las fiestas». 
que se le a de dar y que se escriva a el señor Juan Velluga que pida licencia para pagar los gastos que se hicieren... de los arbitrios que mejor paresciere».

El licenciado Jerónimo de Cevallos, sin embargo, templó el entusiasmo desatado entre los regidores y les obligó a poner los pies en el suelo: por culpa de la Santa Iglesia, que había contravenido la costumbre, y por tanto había roto la concordia establecida con la ciudad, ésta se veía obligada a asumir una pesada carga «en el tiempo de mayor necesidad», cuando ni siquiera podía hacer frente a los gastos que le imponían sus numerosos acreedores y los pagos a jueces de comisión y agentes. Hacer los autos era la obligación del cabildo y no de la ciudad, "pero en caso que su deboción sea tan grande que quiera hazer esta fiesta», debía conseguir el dinero de algún arbitrio y no tocar a los propios ni a lo reservado para los acreedores y los alimentos. Aunque la votación fue favorable al corregidor, a Cevallos no le faltaron votos. Gonzalo de Gaitán afirmó que Toledo no estaba para fiestas ningunas y que hasta que no hubiese un arbitrio claro de donde obtener fondos él contradecía la propuesta.

Los preparativos, no obstante, siguieron adelante, convidándose al tribunal de la Inquisición, a los títulos y caballeros de hábito, y naturalmente al cabildo catedralicio. Éste envió una embajada al Ayuntamiento para agradecer la invitación, pero excusó su asistencia alegando que debían atender a los oficios divinos, y pidió que las representaciones no los perturbaran. A instancias de la ciudad, que trató de evitar la coincidencia de horas, el cabildo expuso el programa ceremonial que iba a seguir:

«los canónigos entrarán a las siete y dirán prima y tercia, que durará una ora, y luego se dirá la missa que durará otra ora, por manera que a las nueve y media saldrá la procesión del día del Corpus Christi para que, conforme a esto, la cibdad pueda acomodar la ora de la representación de manera que se pueda acudir a los oficios divinos y no hazer falta a ellos» 55 .

No hay más información en los libros de acuerdos de ese año, pero sabemos por menciones posteriores que, en efecto, se representaron autos en el día del Corpus por cuenta de la ciudad ${ }^{56}$.

55 Este intercambio de gentilezas entre ambos cabildos puede seguirse en las $A C$ de 6,10 y $15-$ 5-1617, y en los L.A. de 28-4-1617 y de 10, 12 y 24-5-1617.

56 En cambio, los libros de $O F$ de 1617 son los primeros en que no constan libramientos relacionados con los autos. Sólo se mencionan gigantes, violones, danzas y seises. A este propósito, se pagaron dieciséis reales "por el adereço del carro en que entraron los seyses en el choro». Lo mismo ocurre en el siguiente año de 1618, y en 1619 el habitual epígrafe de «Danças y Autos» queda reducido ya al de sólo «Danças» 


\section{QUINTO AUTO: 1618-1636}

Parecía que la crisis estaba resuelta y que los autos habían garantizado su continuidad con sólo pasar de manos eclesiásticas a las seculares. Pero pronto se demostró que Jerónimo de Cevallos tenía toda la razón. Toledo atravesaba una penosa coyuntura debida, entre otros factores, a la crisis de subsistencias de 1606-1607, a la expulsión de los moriscos de 1609 y al asentamiento definitivo de la corte en Madrid, después del paréntesis vallisoletano ${ }^{57}$. En 1615-1616 se registra una crisis de mortalidad que se cebó especialmente en los niños y que, según Pérez Moreda, quizás se debió a la difteria ${ }^{58}$. Y la emigración hacia la corte, tanto desde la ciudad como desde la comarca que tradicionalmente la nutría de los inmigrantes que necesitaba, empezó a percibirse como una verdadera catástrofe. A lo largo de 1617 son numerosas las alusiones a este fenómeno que aparecen en los libros de acuerdos. El 5 y el 24 de abril se acordó incluso que se abrieran diligencias para proceder contra las personas que se iban a vivir a Madrid y contra los carreteros que las llevaban. El 26 de enero de 1618 se trató de «cómo se va disminuyendo su caudal y tratos a causa de averse ido a vivir a la corte la mayor parte de la gente della, así de cavalleros como prebendados de la iglesia y mercaderes e frailes, y que cada día se van yendo más, de que se espera una gran baja y ruina en esta cibdad y su comercio». Acordóse dar cuenta a Su Majestad de las magnitudes de este problema demográfico, así como de la disminución de sus tratos y de «la mucha carga que tienen las alcavalas y otros repartimientos, y que a causa de la mucha necesidad y poca gente y tratos se va empeorando cada día el estado de las cosas, de manera que, si no se remedia, se espera una gran ruina». Tanto era así que el propio Ayuntamiento solicitó la colaboración de la intelectualidad toledana para encontrar soluciones, lo que originó una avalancha de memoriales arbitristas en que participaron algunos miembros de la corporación, como Belluga o el mismo Cevallos ${ }^{59}$.

Ésta era la ciudad que, de acuerdo con su grandeza, había echado sobre sus espaldas la organización de las fiestas que había despreciado el cabildo. En 1618 se utilizó la fórmula que el año anterior, sin que voces sensatas dejasen de llamar a la reflexión. Advirtió Juan Pérez de Rojas que "para introducir un gasto de 800 ducados todos los años, que se an de gastar de fuerza en los autos y fiestas que se an de hazer, se deven mirar los útiles y contras que an de resul$\operatorname{tar} »^{60}$. Y en la balanza terminaron por pesar más estos últimos, pues cuando a principios del año próximo se pidieron instrucciones para iniciar los preparati-

57 Montemayor, Julián: Toléde entre fortune et déclin, Presses Universitaires de Limoges, 1996.

58 PÉreZ MOREDA, Vicente: Las crisis de mortalidad en la España interior. Siglos XVI-XIX, Madrid, Siglo XXI, 1980, p. 297.

59 ARANDA PÉREZ, Francisco José: «La preocupación «arbitrista» en el seno del ayuntamiento de Toledo, por la declinación de la ciudad en un período crítico: 1618-1621», Toletum, 29 (1993), pp. 201-227.

${ }^{60}$ L.A., $\mathrm{n}^{\mathrm{o}} 38,21-3-1618$. 
vos del Corpus, el acuerdo final fue que «no se hagan las representaciones de autos del día del Corpus Christi, aviendo considerado las muchas descomodidades que ay para poderse hazer, y que los gastos que en ello se hazen se quitan a los acrehedores, lo que se acuerda que se haga así por este año» ${ }^{61}$.

Las consecuencias fueron devastadoras para la fiesta. Recién pasado el Corpus de 1619, el regidor don Juan Vaca, que todavía responsabilizaba al cabildo de su dejación, llamaba la atención sobre el enfriamiento de la devoción de los fieles y la desolación que había reinado en el día del Sacramento, porque mucha gente se había marchado «a las fiestas de Yepes y Ajofrín y otros lugares comarcanos, dexando esta cibdad sola de gente, como se vio por esperiencia el año pasado, de manera que no ubo aún gente que acudiese al culto divino con la grandeza y devoción que se deve». Había que encontrar la forma de que la fiesta volviese a celebrarse con el requerido esplendor, y, dado que las representaciones de autos eran imposibles, bien podían correrse toros la víspera del jueves festivo. Juan Gaitán no sólo estuvo de acuerdo, sino que propuso que también se hiciesen juegos de cañas; y el corregidor, adhiriéndose a la mayoría, se puso manos a la obra para pedir al Consejo Real licencia y facultad para gastar de los propios y rentas de la ciudad hasta 2.000 ducados $^{62}$.

La provisión real, con fecha de 14 de mayo, no llegó a Toledo hasta el 20 de mayo de 1620. El documento se remontaba a la época en que el cabildo financiaba los autos, «haciendo muchos carros triunfales de representaciones divinas que se hacían en la dicha yglessia y en diversas plaças y partes donde concurría mucho número de gente, ansí de essa dicha ciudad como de los lugares de su comarca con gran devoción y regocijo». Debido a las discordias entre la corporación eclesiástica y la secular, aquélla había dejado de patrocinar los juegos escénicos y Toledo, aun habiéndolos organizado durante dos años gastando en cada uno 600 ducados, había tenido que desistir de sus esfuerzos. «Y el año pasado de seiscientos y diez y nueve no se avían hecho las dichas representaciones ni este presente año las tenía desprevenidas so color de dezir que no se podía sacar de los propios el dicho gasto por estar consignado por nos para la paga de los acrehedores». El consiguiente deslucimiento de la fiesta era razón suficiente para que el Consejo Real conminase a la ciudad a que, usando de la facultad que ya tenía concedida, volviese a encargarse de las fiestas; y si no hubiese dinero suficiente, se mostraba abierto a considerar otros arbitrios, como el arriendo del oficio de un tesorero de alcabala o del mesón de la fruta y casa de comedias que pertenecía a la ciudad, pues a nadie podía interesar más que hubiese autos en el Corpus, ya que atraería a la ciudad a las mejores compañías ${ }^{63}$.

Cuando se acabó de leer esta provisión los regidores quedaron suspensos. Al procederse a la votación, los cinco primeros a quienes correspondía expresar su

61 L.A., $\mathrm{n}^{\mathrm{o}} 38,22-2-1619$.

62 L.A., $\mathrm{n}^{\mathrm{0}} 39,10-7-1619$.

63 L.A., $\mathrm{N}^{\circ} 40,20-5-1620$. La votación que se refiere a continuación se desarrolló ese mismo día, inmediatamente después de leerse esta provisión. 
parecer, con el corregidor al frente, pidieron escuchar. Fue el regidor Jacobo Pinelo quien se atrevió a argumentar su voto en primer lugar, y ello por escrito. Se refirió con nostalgia a los buenos tiempos en que los autos se hacían en la santa Iglesia, que,

«después de aver edificado devotamente al pueblo con los oficios divinos, música y solemníssima processión, le alegrava y regocijava estrañamente con las galas y vestidos y carros de representación que andavan por las calles, con que este día se diferenciava de los demás festivos del año y acrecentava la reverencia y estimación de tan divino misterio».

Contrastaba con ello la soledad y desconsuelo que ahora imperaba, cuando los vecinos se iban a otras partes a celebrar la fiesta con representaciones, toros, cañas, fuegos y otras demostraciones festivas. Habiendo sido Toledo la primera en celebrar esta fiesta para confusión y espanto de los herejes, era inadmisible que ahora se desentendiese de ella. Dios no podía estar indiferente y sin duda había empezado a mostrar su ira. Y Pinelo hizo notar que «los quatro años que (h)a que no se haçe esta fiesta an sido los más rigurosos que a tenido esta ciudad desde su fundación y en que más a declinado de su antigua grandeça». La situación no tenía fácil solución, pero la ciudad no debía escatimar esfuerzos para buscar arbitrios que proporcionasen el dinero necesario de forma suave y conforme a los privilegios de Toledo. Algunos votos, incluido el del corregidor, se inclinaron en favor de la opinión de Pinelo. Juan Antonio Pinelo sostuvo que, buscándose arbitrios que no perjudicasen a los acreedores, habían de hacerse autos, y correrse toros y jugarse cañas. Para alegrar la fiesta se acordó correr catorce toros el miércoles, víspera del Corpus. De este modo, la gente encontraría un aliciente para quedarse en Toledo y asistiría al día siguiente a la procesión.

Pero no todos se mostraron concordes. Juan de Paredes señaló que era un daño muy grande convertir en costumbre lo que se había podido hacer una o dos veces, y que de ello resultaría no pagar lo que tanto necesitaban escuderos honrados con familia y viudas recogidas con hijas doncellas, sumidas en la pobreza y la necesidad. «A los unos les obliga a acer travesuras y delitos graves, a las viudas e doncellas a acer ofensas de nuestro Señor gravísimas, por manera que para hacer fiestas profanas se trata de servir a nuestro Señor quitando el dinero a los pobres onrados». Y ello sin contar los pleitos de la ciudad que se dejaban perder por no tener con qué pagar los gastos. En las mismas razones abundó Juan de Toro, quien estimó que para celebrar estas fiestas de acuerdo a su grandeza Toledo necesitaría 1.500 ducados anuales. Además, le serían necesarios carros triunfales con el ornato correspondiente,

«y esta ciudad no tiene casa para poderlos fabricar en el estado que conviene, y la planta de esta ciudad es tan áspera que, aviendo de señalar sitio donde se hiciesen e guardasen, quando se truxesen a las plaças donde se ubiese de exercer e representar las ystorias que se les diesen a los autores, vendrían echos pedaços... y 
ansimismo tendríamos grande yncompatibilidad por... no poderse acer las representaciones a la ora y al tiempo que fuese necesario por ser el cavildo de la santa yglesia tan puntual en celebrar los divinos oficios».

No, era el cabildo quien debía recuperar costumbre tan inmemorial, «porque se les acude con los diezmos» y porque la obra de la catedral es tan rica que atesora 45.000 ducados de renta. Días más tarde propondría el mismo Toro que se hiciesen diligencias judiciales para obligar al cabildo a lo que debía.

El 10 de junio se leyó una nueva provisión en la que el rey concedía por fin su licencia para que Toledo pudiera gastar ese año los 800 ducados solicitados de sus propios ${ }^{64}$, pero los festejos se limitarían a la gran corrida de toros del miércoles. Sin embargo, hasta en esto se iban a producir los habituales roces entre ambos cabildos. El eclesiástico se quejó de que los toros impedirían a la gente asistir a las vísperas; el corregidor, enfadado, no quería volverse atrás, pues se trataba de un acuerdo que había pasado por ciudad y dejar de hacer la corrida perjudicaría las haciendas de los que habían montado la plaza y los tablados, así como algunos emolumentos del propio Ayuntamiento. Pero el Consejo Real vino en esta ocasión a apoyar las pretensiones del cabildo.

Y de este modo se llegó a la víspera del Corpus, miércoles 17 de junio, sin haberse resuelto la cuestión, y ello con la plaza lista y los toros preparados. La corporación se reunió por la mañana para votar y una lluvia de críticas se abatió sobre el corregidor. A nadie le parecía bien ahora la idea de correr los toros en la víspera, pues a los inconvenientes que ponía la Iglesia se sumaba el hecho de que, estando próxima la procesión, se había de trabajar contra el reloj para deshacer los tablados y desescombrar las calles barreadas; y lo peor era que no había otro día, entre el Corpus y la octava, que pareciese adecuado, pues en todos ellos el Santísimo Sacramento estaba expuesto en iglesias, conventos y en la propia catedral, y sería muy impropio desviar a la gente de sus devociones. Compartían todos la necesidad de que los toros, a esas alturas, tenían que correrse, pero no había forma de encontrar una fecha conveniente. Unos propusieron esperar a que se terminasen las vísperas, otros querían retrasarlo a la semana siguiente, y unos terceros a la fiesta de San Juan Bautista. Los más radicales, como Juan Pérez de Rojas o Bernardino Osorio de Aguilera, fueron del parecer de que los toros se supendieran «por ahora» o en el plazo de diez años, pues «de semexantes juntas e fiestas se ofrezen quistiones, heridas e muertes, y otras de muy notable disgusto». Se hacía imposible llegar a un acuerdo. El corregidor suspendió la reunión y volvió a convocarla a las cuatro de la tarde, pese a la nulidad de tal procedimiento, que alguien denunció. Tomás Paredes tomó la palabra para recordar cierta desgracia que el día anterior había sucedido a don Esteban Carrillo, «sucesor de tantos maestres de Santiago e grandes de España», lo que, por razones que desconozco, le sirvió para proponer que

${ }^{64}$ L.A., , $\mathrm{n}^{\circ}$ 40, 10-6-1620. La provisión tenía fecha de dos de junio. 
«no deve aver toros en honze años, e así lo contradize por todo este tiempo». Si el cabildo había dejado de hacer los autos por considerarlos profanos, "quánto más profanidad consiste daños, perjuicios, ocasiones de muertes de ombres en pecado mortal». Juan de Toro, fiel a su apellido, contradijo esta pretensión, pues de ese modo la ciudad terminaría por despoblarse el día de la fiesta. El licenciado Cevallos impuso una vez más su sentido común afirmando que al corregidor le correspondía fijar un día, pasada la octava, en que se corriesen los toros,

«e se haga la fiesta que la ciudad tiene determinada e pasada, porque lo que causaría nota e murmuración al gobierno público, e más estando tan empeñados en esta fiesta y contratados los toros, hechos tablados, lo qual no parezería bien tornarlos a deshazer con costa de los que los an hecho».

El corregidor, naturalmente, rechazó el requerimiento de Pérez de Rojas y se adhirió al parecer de Cevallos, defensor de sus prerrogativas. Y unos días más tarde, el 10 de julio, fijó la fecha del festejo taurino para el lunes 13 de ese mes.

Desde este año las deliberaciones sobre la fiesta del Corpus desaparecen completamente de los libros de acuerdos, a no ser para tratar de la cera y de vestir los sofieles para la procesión, acto único al que ahora se había reducido la fiesta. No se trataba sólo de que ya no se representasen autos; refiriéndose a las corridas de toros, recordó el corregidor en 1626 que "no se han hecho fiestas en tres años». La ciudad no estaba para hacer dispendios, pero gozaba de la facultad de poder organizar un festejo taurino anualmente «sin concurso de acreedores y sin embargo de embargos». Aunque algunos regidores contradijeron la idea por estar la ciudad muy alcanzada, el corregidor logró recuperar ese año la corrida anual, aunque significativamente no fue programada en torno al Corpus $^{65}$. Si acaso, cuando entraba la primavera, alguien hacía un llamamiento para que Toledo se esforzase en recuperar el antiguo esplendor de su fiesta sacramental, alegando el desconsuelo y soledad con que ahora se vivía ese día. Diego de Robles Gorbalán lo intentó en 1629, pero el corregidor y la mayoría de munícipes decidieron que no hubiese fiestas, pues antes que ellas estaban los acreedores $^{66}$. Para mayor desgracia de las artes escénicas en Toledo, el 28 de agosto de 1630 se desató un gran incendio en el mesón de la fruta y casa de comedias que privó a la ciudad de su único teatro estable durante más de dos años, hasta que el nuevo edificio fue construido por cuenta del Ayuntamiento, principal perjudicado porque de su explotación sacaba una buena renta que era destinada precisamente al pago de los acreedores ${ }^{67}$.

${ }^{65}$ L.A., $\mathrm{n}^{\mathrm{0}}$ 46, 3-7-1626. El 6 del mismo mes se acordó correr catorce toros el día después de Santiago.

66 L.A., $\mathrm{n}^{\circ} 49,20-31629$ y $23-4-1629$.

67 Según se recuerda en el L.A. $\mathrm{n}^{0}$ 53, en la sesión celebrada el 20-4-1633, el día de San Agustín, 28 de agosto de 1630, a las doce de la noche, comenzó un incendio tan grande que, «por ser la dicha cassa libre de vivienda, quando se reconoció el fuego se avían quemado las dichas cassas 
En 1630 y 1631 se intentó remediar el descaecimiento del Corpus corriendo los toros el martes previo a la fiesta ${ }^{68}$, pero ni siquiera en eso el regimiento se mostraba unánime. Don Alonso de Alcocer señaló en 1632 que, lejos de enaltecer el Santo Sacramento, los toros lo infamaban, y pidió «que no haya toros en el Corpus por los daños y muertes que se siguen». Hubo quien, como Juan de Palma, opinó que «ni en esa ocasión ni en ninguna otra se corran», pero la mayor parte se contentó con trasladarlos más allá de la octava ${ }^{69}$, como así se observó en años sucesivos ${ }^{70}$.

\section{DESENLACE: 1637-1645}

No fue hasta 1637 , veinte años después de que se representasen los últimos autos en una fiesta del Corpus, cuando el Ayuntamiento se decidió a recuperarlos por todos los medios. Según el corregidor, la primada Toledo, que contaba con el mayor templo de Europa y había sido la primera en festejar el Sacramento, tenía la obligación de celebrarlo de acuerdo con su grandeza. Propuso en consecuencia que «se agan fiestas con autos y se agan carros para las representaciones deste día» y para pagarlas se pidiese facultad para gastar cada año 1.500 ducados sacados del derecho de medio real de la seda, ya que los propios estaban destinados al pago de los acreedores. Lo que diferenció a esta propuesta de las de años anteriores es que esta vez hubo voluntad de llevarla adelante por parte del regimiento entero, llegando a ofrecer para este empeño la mayoría de los caballeros una parte de su salario ${ }^{71}$. Inmediatamente se nombró a los comisarios encargados de preparar la fiesta y el corregidor dispuso que «si se pudieren hacer las representaciones a lo dibino, se agan, y que se empiecen después de acabadas las vísperas y proseción de la santa yglesia». Los toros también se fijaron para el martes previo al Corpus y se acordó que «el día de los toros se dé aloja y agua de nieve en el mayordomo de Toledo al Ayuntamiento». Finalmente pudieron concertarse los autos y se sortearon entre regi-

\footnotetext{
y mesón y red del pescado y otras muchas de particulares con quien alindavan, sin que quedase en toda la dicha cassa messón cossa alguna de fábrica ni madera en que se pudiesse reconocer averla avido en la dicha cassa messón, pues asta las colunas de piedra quedaron arruinadas y consumidas del fuego, y aviendo cessado con él el arrendamiento del dicho mesón y usso de comedias, por quedar sólo un corral sin puerta ni ventana ni otro género de edificio». Ese año el mesón había proporcionado una renta de $680.000 \mathrm{mrs}$. Cuando se planteó la reconstrucción, nadie hizo postura, por lo que el Ayuntamiento tuvo que encargarse directamente de las obras. Aunque éstas no se habían finalizado aún, comenzó a representarse en el nuevo teatro en diciembre de 1632.

68 L.A., $\mathrm{n}^{\mathrm{o}} 50,8-5-1630 \mathrm{y} \mathrm{n}^{\mathrm{0}} 51,2-6-1631$.

69 L.A., $\mathrm{n}^{\circ} 52,9$ y 16-6-1632.

70 En 1633 la fiesta de toros se hizo el 18 de julio, el 9 de julio en 1635, el 30 de junio en 1636. Véanse los L.A., $\mathrm{n}^{\circ} 53,20-4-1633 ; \mathrm{n}^{\circ} 55,18-4-1635 ;$ y n $^{\circ} 56,21-4-1636$.

71 L.A., $\mathrm{n}^{\circ} 57,6,8$ y 15-5-1637. Hasta veintiún regidores ofrecieron cantidades que sumaron unos 300 ducados, en cuantías que oscilaron entre los tres y los diez mil maravedís.
} 
dores y jurados las ventanas de la casa consistorial para verlos, ya que se dispusieron los tablados delante de su fachada principal. Fueron invitados al espectáculo los miembros del tribunal del Santo Oficio y del cabildo, aunque este último, sin abandonar su coherencia, se excusó por tener «por fuerza que asistir a las oras con el Santíssimo». La ciudad parecía exultante y el día de la víspera valoró los muchos gastos que se estaban haciendo, pero para declarar a continuación que «muchos y mayores era justo ubiese en tan gran día» y aplicó todo lo obtenido en el festejo taurino del día anterior al sostenimiento de la fiesta ${ }^{72}$.

Los únicos datos sobre las representaciones que se hicieron nos informan de que el contador toledano Blas de Mesa compuso una loa dedicada a la ciudad que luego se imprimió ${ }^{73}$. Se han conservado el contrato y la memoria con las condiciones que el maestro de carpintería Pedro López había de observar en la construcción de un balcón de cuatro gradas para que se sentasen los ediles, un tablado para la representación en medio de la plaza del Ayuntamiento y un pasadizo desde las casas arzobispales a dicho tablado, así como otro en la plaza de Zocodover. También se mencionan las apariencias, pero sin dato alguno que sirva para identificar los autos que se representaron ${ }^{74}$.

La experiencia en la restauración de las fiestas del Corpus toledano resultó extraordinariamente satisfactoria. En seguida se nombraron los comisarios que habían de preparar las del próximo año y se acordó premiar a los que tan bien las habían organizado este año «con la mayor onra que puede acer a sus ciudadanos cavalleros de su ayuntamiento, enbiándoles cavalleros comisarios desta casa dándoles gracias del favor que en esta ocasión an dado a la ciudad» ${ }^{75}$.

El esfuerzo llevado a cabo en 1637 dio sus frutos en la continuidad de los años siguientes. Aunque en 1638 se pensó en aplazarla por estar «la gente afligida por la falta de pan», la fiesta de toros se hizo también el martes previo al Corpus. Los comisarios visitaron las calles y dispusieron los toldos para la procesión, se concertó hacer los tablados para los autos ${ }^{76}$ y se cursaron las invitaciones de rigor. Para ello se tomaron del obligado de las carnicerías, de acuerdo con la facultad concedida a la ciudad, hasta mil ducados, teniendo buen cuidado en no tocar los precios de las carnes, que estaban muy altos ${ }^{77}$. También este año pareció bien el mucho lucimiento de la fiesta y, como el pasado, los comi-

72 L.A., $\mathrm{n}^{\circ}$ 57, 20-5-1637, 8 y 10-6-1637. Este último día, víspera del Corpus, se acordó que los dos toros que habían quedado vivos y el precio en que se remataran los muertos sirviesen íntegramente para hacer frente a los gastos de la fiesta.

73 L.A., $\mathrm{n}^{\circ}$ 57, 30-6-1637.

74 AMT, caja 881, Festejos del Corpus Christi. Se libraron al carpintero 1.650 reales por su trabajo.

75 L.A., $\mathrm{n}^{\mathrm{0}} 57,12-6-1637$.

76 AMT, caja 881. Esta vez se concertaron los tablados con el carpintero Sebastián Vázquez, al que se pagaron 2.450 reales. En la memoria no se perciben muchas novedades con respecto al año anterior.

${ }_{77}$ L.A., $\mathrm{n}^{\mathrm{o}}$ 58, 8-3-1638; 5, 10, 19, 21, 26 y 31-5-1638. 
sarios fueron felicitados oficialmente ${ }^{78}$. Al fin se había encontrado la fórmula para financiar las fiestas. La víspera del Corpus de 1639 volvió a recibirse la facultad que daba licencia a la ciudad para sacar los mil ducados de la tabla de Rey, obligado de las carnicerías. Con este dinero los comisarios podían atender a la participación del Ayuntamiento en la procesión y a la concertación de los toros y los autos, elementos que otorgaban su personalidad y su atractivo a la fiesta del Corpus. Para este año conocemos incluso la compañía que hizo las representaciones por una carta en que Luis López, autor de comedias, informaba de que las tenía concertadas con los diputados del Ayuntamiento y de que ya tenía estudiados una loa y un auto ${ }^{79}$.

Llegamos así al año de 1640, en que podemos situar el comienzo del período en que mayor auge alcanzaron las fiestas barrocas del Corpus toledano. El propio Calderón de la Barca escribió por encargo del Ayuntamiento el auto de Psiquis y Cupido, para el que ideó un programa de espectaculares apariencias que comunicó por carta a los comisarios municipales ${ }^{80}$ y una loa en la que, como no podía ser menos, ensalzaba la magnificencia de la ciudad y de sus próceres. Toledo era cabeza y escuela de las otras ciudades del reino, noble por su antigüedad, silla de los reyes godos, corazón de España, morada de la fe y aventajaba a todos los reinos en la celebración de la fiesta del Corpus. La loa jugaba alegóricamente con las bodas de Amor-Cristo con su Iglesia-iglesia catedral-Toledo, en honor de las cuales se hacían ofrendas que, significando justicia, pureza, caridad y sencillez, simbolizaban los distintos gremios que ejercían su actividad en la ciudad: herederos y labriegos, pedreros y albañiles, espaderos, plateros, caperos, sombrereros, guanteros y hortelanos ${ }^{81}$. La justicia convidaba al auto, en el que se divinizaba un antiguo mito clásico contenido en El asno de oro de Apuleyo. Maltratada por el Mundo, la Idolatría, el Judaísmo y la Apostasía, la Fe (Psiquis) era salvada, y posteriormente perdonada, por Cupido (Cristo), que ante una mesa con una hostia y un cáliz proclamaba su perdón a la humanidad y finalizaba el auto volviendo a despertar el orgullo de los toledanos:
«Aqueste monte,
pues contiene gentes varias,
y en el idioma caldeo

78 L.A., $\mathrm{n}^{\circ} 58,4-6-1638$.

79 AMT, caja 372, Cartas año 1637. Decía López que «porque a tanto que estoy en esta ciudad representando y aber entrado las calores, se me an acabado las comedias, por lo cual no tengo que hacer, suplico a $\mathrm{v} \mathrm{s}^{\mathrm{a}}$ me dé licencia para salir a hacer una fiesta víspera de Pascua de Espíritu Santo, obligándome a estar aquí lunes siguiente, que es diez días antes del corpus, que en ello se me hará gran limosna y merced, porque con ella costearé mi compañía».

80 Martínez Gil, Fernando, García Ruipérez, Mariano, y Crosas, Francisco: «Calderón de la Barca y el Corpus toledano de 1640: recuperación de una carta autógrafa en el Archivo Municipal de Toledo», Criticón, 91 (2004), pp. 93-120.

81 Calderón de la Barca, Pedro: Autos sacramentales, II, ed. de Enrique Rull Fernández, Madrid, Turner (Biblioteca Castro), 1997, p. 297 y ss. 
junta de muchos se llama

Toletot, Toletot sea, y Toletot en España, será desde hoy el lugar donde más la Fe se ensalza».

Los tablados en las plazas del Ayuntamiento y Zocodover, así como la fabricación de las apariencias, que debieron ser magníficas y espectaculares, corrieron a cargo de los maestros carpinteros Pedro López Briceño, Sebastián Vázquez y Esteban López. Se citan, por ejemplo, un dragón de madera, con cola, garras y alas, echando fuego, y en el que va cabalgando un caballero; un tridente del que sale agua; una galera con doce remeros y un grumete en la gavia, un peñasco que se abre para dejar ver un jardín deleitoso, el vuelo de una persona hasta lo alto de una torre...

Por haber desaparecido los contratos, ignoramos cuál fue la compañía que estrenó en Toledo Psiquis y Cupido y el resto de los autos ${ }^{82}$. Sí sabemos que la muestra se hizo en la casa de comedias y que, según obligaciones de años posteriores, los autores se comprometían, como haría Pedro de la Rosa en 1643, a

«que el jueves, día del Corpus por la tarde en el sitio y como es costumbre representará con su compañía dos autos, dos loas, dos entremeses, dos bailes y un sarao, y por la mañana en la plaza de Çocodover en dos sitios donde se señalare, de manera que por la mañana ha de hacer dos representaciones en dos partes, y ansimismo el viernes siguiente por la tarde representarán los dos autos que ha de representar el jueves en la forma como se ubieren hecho el día de la fiesta» ${ }^{83}$.

Junto a los autos, entre los que sin duda debió de destacar el de Calderón, el Corpus toledano se vio amenizado por la gran corrida de toros que, como empezaba a hacerse habitual, se celebró el martes de la semana del Corpus, con los catorce toros de rigor corridos en la plaza de Zocodover. Mientras en Barcelona, aquel 7 de junio, se desarrollaban los acontecimientos que harían recordar aquel día como el Corpus de Sangre, la procesión discurrió en Toledo con total normalidad y extraordinario lucimiento, para lo cual, como era costumbre, se

82 Los documentos municipales mencionan también una loa y auto de Blas Fernández de Mesa que debía estar relacionado con la historia de Jasón.

83 AMT, caja 881, Festejos del Corpus Christi, 12-3-1643. «Y el dicho autor ha de poner y vestir la compañía de todo lo necesario para auto y comedia y entremeses y bailes, de trajes y lo demás que fuere necesario, y ha de estar en esta ciudad la dicha compañía 34 días antes del corpus para lo estudiar y no a de empezar a representar en esta ciudad hasta los dichos 34 días antes del corpus, y faltando algún día pagará al censo de pena por cada día y no ha de sacar en todos los dichos 34 días antes del corpus ni entrar en esta ciudad a representar el dicho tiempo pena de 500 ducados para el ospital del rey desta ciudad y todavía ser apremiado acello. Y si el viernes no se hiciere en la plaza del Ayuntamiento, la fiesta la ha de hacer en la parte que se le hordenare por los señores comisarios en esta ciudad». 
colgaron los toldos, se adornaron las calles de la carrera, se esparcieron romero y otras hierbas olorosas y se empedró el pavimento con cascote de ladrillo ${ }^{84}$. No faltaron las danzas, tanto de gitanas como de gigantes y seises, así como otras muchas diversiones populares, como volatines y ministriles. El Corpus volvía a ser aquella fiesta mestiza, a la vez religiosa y profana, solemne y popular, en la que, según pedía la bula de Urbano IV, que la instituyera en 1264, «todos, assí Clérigos, como legos, canten con gozo y regozijo cantares de loor» ${ }^{85}$.

Y así continuó celebrándose al menos hasta 1645 , años de los que se ha conservado una documentación muy valiosa en el Archivo Municipal de Toledo, en donde se incluyen las obligaciones con los carpinteros para la fabricación de los tablados, las memorias de apariencias y algunos contratos con las compañías de representantes. Sabemos así que las cantidades pagadas a los carpinteros fueron en aumento ${ }^{86}$ y que intervinieron las compañías de Rueda (1642), Pedro de la Rosa (1643), Antonio de Prado (1644) y Pedro de Ascanio (1645). Es difícil, a través de las apariencias, llegar a identificar los autos que se representaron, si bien cabría especular con Galán discreto y valiente de Mira de Amescua, o Los trabajos de Tobías y La viña de Nabot, ambas del toledano Francisco Rojas Zorrilla. Está fuera de toda duda, además, la vinculación de Calderón con el Corpus toledano. Como se ha visto, en 1640 escribió para la ciudad su auto de Psiquis y Cupido, y en 1644 fue representada La humildad coronada, a cuya memoria de apariencias, probablemente perdida, hacen mención los papeles municipales, así como a dos memorias referidas al año $1642^{87}$.

Ignoro por el momento si el Ayuntamiento toledano continuó patrocinando las representaciones del Corpus con tanta magnificencia, aunque el hecho de que este tipo de documentación se circunscriba al período 1637-1645, parece indicar que no fue así. A ello se suma el endeudamiento y la presión fiscal que, de forma agudizada, se abatieron sobre la ciudad, cuyo rango y grandeza histórica se compadecían cada vez menos con su situación real ${ }^{88}$.

Aun a falta de proseguir la historia del Corpus toledano con posteriores y necesarias investigaciones, se ha tratado de analizar aquí un gran cambio, extraordinariamente significativo para la historia de las mentalidades, en sus for-

84 «Calderón de la Barca y el Corpus toledano de 1640...», op. cit., pp. 100-101.

85 MARTínez Gil, Fernando, y Rodríguez GonzÁlez, Alfredo: «Del Barroco a la Ilustración en una fiesta del Antiguo Régimen: el Corpus Christi», en Franco Rubio, Gloria A.(coord.): De mentalidades y formas culturales en la Edad Moderna. Cuadernos de Historia Moderna. Anejos I (2002), Universidad Complutense de Madrid, pp. 151-175.

86 De los 1.650 reales que se pagaron a Pedro López Briceño en 1637 se pasó a los 2.450 de $1638,4.000$ en $1640,4.100$ en 1642 y 1643 , y 8.800 en 1644 .

87 «Calderón de la Barca y el Corpus toledano de 1640...», op. cit., , pp. 107-108.

88 RodrígueZ De GRACIA, Hilario: El crepúsculo patrimonial de Toledo, Ayuntamiento de Toledo, 1999. Según las cuentas de propios y arbitrios, los gastos del Ayuntamiento superaron a los ingresos entre 1620 y 1634, salvo los años de 1625 y 1631. Curiosamente el año 1637 también fue deficitario, aunque todos los siguientes hasta completar la primera mitad del siglo, excepto 1644 , resultaron favorables. Ibidem, p. 152. 
mas de celebración. Proveniente de los siglos medievales e impulsada por las necesidades de la ideología contrarreformista, la fiesta del Corpus no se limitó a celebrarse año tras año reproduciendo su ritual, sino que se vio sometida a importantes transformaciones cuyo estudio arroja bastante luz sobre la evolución de las sociedades del Antiguo Régimen. Mucho antes de que la Ilustración abominase de las mezclas que percibía en ella de elementos religiosos y profanos, una parte del clero, cada vez más numerosa, trató de purificarla de aquellas manifestaciones festivas que en un tiempo había compartido, pero con las cuales se sentía cada vez menos identificada. Tampoco hay que descuidar, como parte del problema, los conflictos jurisdiccionales y protocolarios que el cabildo acostumbraba a tener con los poderes municipales, ni la competencia que encontraba en la corte a la hora de hacerse con los servicios de los mejores representantes para dar el mayor realce a su fiesta.

Después de un prolongado y agotador debate, en el que ambas posiciones encontradas jugaron sus bazas con apasionado ardor, los tradicionales autos del Corpus fueron expulsados, como había hecho el propio Jesucristo con los mercaderes, del templo al que infamaban con sus pantomimas y representaciones contaminadas de profanidad. La decisión no fue bien entendida por las instancias seculares y por los medios populares que habían venido participando también en la fiesta. Por un lado, el Ayuntamiento lamentaba que la iglesia primada de España, y una ciudad que se tenía por cabeza del reino, no celebrasen una fiesta tan importante como la exaltación del Santísimo Sacramento con el debido esplendor, como así seguían haciéndolo otros lugares; por otro, vecinos y comarcanos desamparaban la ciudad el día de la fiesta y acudían a otras partes donde la diversión estaba asegurada. Los regidores quisieron, pues, asumir con toda rapidez las obligaciones de que habían hecho dejadez los canónigos y encargarse del patrocinio de las representaciones, cuya financiación habría de recaer en las arcas municipales. La penosa situación económica en que estaba sumido el Ayuntamiento pronto hizo ver que los entusiasmos iniciales no tendrían continuidad. Los debates pasaron de las actas del cabildo a los libros de acuerdo municipales, y con ello también cambiaron radicalmente los argumentos. Los regidores ya no discutían sobre objeciones morales, sino de prioridades económicas. Unos anteponían los deberes religiosos de una ciudad tan cristiana; otros, más realistas, ponían de manifiesto el endeudamiento creciente y los problemas sociales. La tozuda realidad acabó por convertir lo que en un principio hubiera podido ser sólo un relevo de patrocinadores en una larga y profunda crisis de veinte años, en que el otrora esplendoroso Corpus toledano quedó varado en la mediocridad.

Habría que indagar sobre las razones por las que, precisamente en 1637 , los regidores superaron su anterior resignación y se lanzaron decididamente a la recuperación del esplendor perdido. Ciertamente lograron su propósito y el Corpus volvió a brillar por unos años, haciendo posible, entre otras cosas, la importante colaboración de Calderón. El orgullo cívico de una ciudad, defendido por sus próceres, y un franco apoyo popular, lograron preservar un tiempo 
los elementos esenciales sin los que no podían entender su fiesta del Corpus. El brillo recuperado debió de durar pocos años, o al menos eso es lo que deja presagiar la documentación conservada en el Ayuntamiento toledano. No obstante, se hace necesario el examen de los datos que se refieren a las décadas posteriores a los Corpus de Calderón para llegar a conclusiones definitivas y esclarecer si los autos se habían extinguido o no, bien por motivos económicos o ideológicos, cuando les llega la prohibición de 1765 . 
